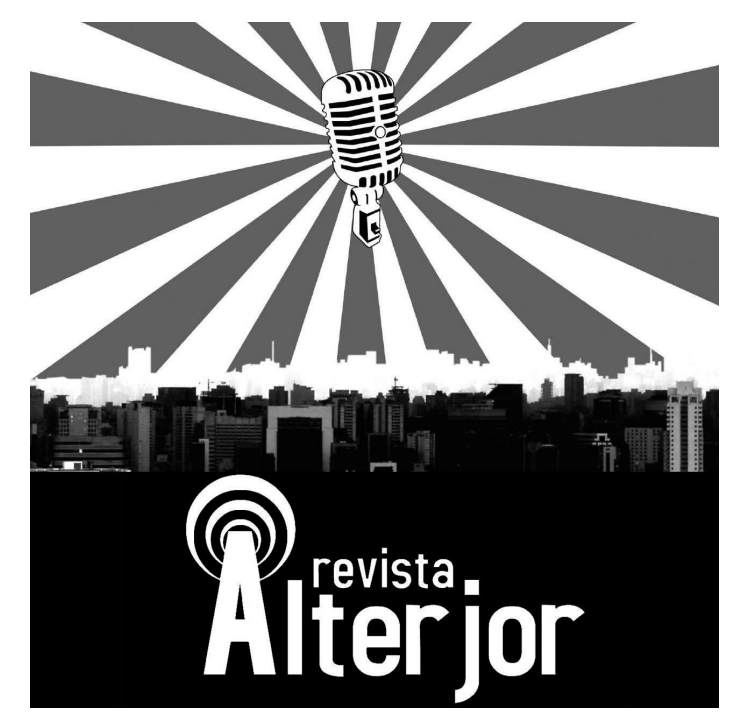

\title{
VALORES-NOTÍCIA DA IGREJA CATÓLICA NO BRASIL: ANÁLISE DO CONTEÚDO DE 44 NOTÍCIAS INSTITUCIONAIS PUBLICADAS NO SITE DA CNBB
}

\author{
Gláucia da Rocha Cardoso ${ }^{1}$ \\ Eliane Muniz Lacerda ${ }^{2}$ \\ Robson Dias ${ }^{3}$
}

RESUMO: $O$ artigo analisa os valores-notícia de conteúdo jornalístico no site da Conferência Nacional dos Bispos do Brasil - CNBB. Os valores-notícia são essenciais na produção do conteúdo jornalístico dos veículos e também na produção de conteúdos institucionais das entidades. Os valores-notícia são utilizados para designar as qualidades dos fatos, isto é, as características que os tornam noticiáveis para dada organização. E acabam revelando o perfil e discurso das organizações com a mídia e com seus públicos. Em busca desse perfil noticioso, foram analisadas, por meio da Semana Artificial (HERSCOVITZ, 2007, P. 131) e da Análise de Conteúdo (BARDIN, 1977) o corpus de 44 matérias disponíveis no site da instituição. O período de análise abrange três meses de publicações de notícias no site da Conferência, de março a maio de 2017, visto que dois grandes eventos organizacionais ligados à Igreja Católica aconteceram em meados da data escolhida: a Campanha da Fraternidade e a Assembleia Geral da CNBB. É um período que reúne todo o episcopado brasileiro, com o objetivo de discutir questões importantes para a Igreja. Os resultados mostram que um perfil noticioso sobre o que é pauta institucional na maior organização católica do Brasil.

PALAVRAS-CHAVE: Jornalismo. Notícia Institucional. Valores-notícia. CNBB. Igreja Católica.

\footnotetext{
Jornalista e pesquisadora colaboradora do PPGCOM - Universidade Católica de Brasília. E-mail: glaucia@ucb.br

${ }^{2}$ Docente no curso de Comunicação na Universidade Católica de Brasília (UCB) e assessora da Conferência Nacional dos Bispos do Brasil (CNBB). E-mail: eliane.lacerda@p.ucb.br

${ }^{3}$ Professor e pesquisador do mestrado em Comunicação da Universidade Católica de Brasília. E-mail: rbsn.dias@gmail.com
}

\section{Revista ALTERJOR}

Grupo de Estudos Alterjor: Jornalismo Popular e Alternativo (ECA-USP)

Ano 11 - Volume 02 - Edição 24 - Julho-Dezembro de 2021

Av. Professor Lúcio Martins Rodrigues, 443, Cidade Universitária, São Paulo, CEP: 05508-020 


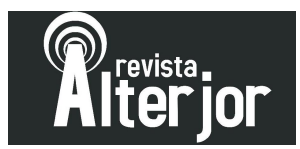

ABSTRACT: The article analyzes the news values of journalistic content on the website of the National Conference of Bishops of Brazil - CNBB. The news values are essential in the production of the journalistic content of the vehicles and also in the production of institutional content for the entities. News values are used to designate the qualities of the facts, that is, the characteristics that make them noticeable for a given organization. And they end up revealing the profile and discourse of organizations with the media and their audiences. In search of this news profile, through the Artificial Week (HERSCOVITZ, 2007, P. 131) and Content Analysis (BARDIN, 1977), the corpus of 44 articles available on the institution's website was analyzed. The analysis period covers three months of news publications on the Conference website, from March to May 2017, as two major organizational events linked to the Catholic Church took place in the middle of the chosen date: the Fraternity Campaign and the CNBB General Assembly. It is a period that brings together the entire Brazilian episcopate, with the aim of discussing important issues for the Church. The results show that a news profile about what is institutional agenda in the largest Catholic organization in Brazil.

KEYWORDS: Journalism. Institutional News. News Values. CNBB. Catholic Church.

\section{INTRODUÇÃO}

Este artigo apresenta investigar a produção de notícias publicadas pelo site da CNBB, visando indicar os valores notícia da instituição. Enquanto instituição religiosa e social, a Conferência Nacional dos Bispos do Brasil (CNBB) possui interesses em disseminar e cuidar da sua imagem. Elizabeth Brandão (2003) e Bruno Carvalho (2003) vão dizer que a imagem institucional se modifica em aura que reveste toda empresa e transmite valores, princípios e ideias.

A preocupação com os meios de comunicação, tanto no âmbito do conhecimento como da prática, não é de agora. Ao longo do tempo, a Igreja Católica teve de se adequar ao uso dos meios até chegar às mídias digitais, perpassando por veículos como a jornais, revistas, rádio, cinema e a televisão.

No decreto Inter Mirífica, aprovado em 4 de dezembro de 1963, a Igreja reconheceu a importância dos meios de comunicação. No documento é declarado que este instrumento serve para que as informações cheguem às pessoas de forma adequada. Anos depois, no que diz respeito às mídias digitais, a Igreja atribui à Internet um papel relevante

\section{Revista ALTERJOR}

Grupo de Estudos Alterjor: Jornalismo Popular e Alternativo (ECA-USP)

Ano 11 - Volume 02 - Edição 24 - Julho-Dezembro de 2021 Av. Professor Lúcio Martins Rodrigues, 443, Cidade Universitária, São Paulo, CEP: 05508-020 


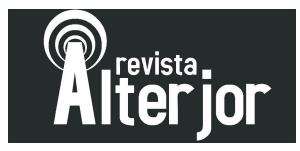

para as atividades e os programas. No documento Pontificado para as Comunicações Sociais: Igreja e Internet (2002) consta que o uso desta ferramenta possibilita a evangelização, que inclui a reevangelização e a nova evangelização, obra missionária tradicional, a catequese, a veiculação de notícias e informações, além de proporcionar alguns tipos de conselho pastoral e de direção espiritual.

A produção de conteúdo nas mídias digitais possui um extenso campo. Este artigo tratará da notícia institucional da Igreja Católica no Brasil, especificamente aquelas produzidas para o site da CNBB, visando analisar os valores-notícia de conteúdo jornalístico da instituição. Para isto, propõe-se a responder à seguinte questão: quais são os valores-notícia presentes nas matérias divulgadas no site da CNBB?

As notícias são um recorte da representação da realidade, entretanto, a forma e o conteúdo das notícias institucionais são moldados pelos interesses institucionais e também pela opinião do público a respeito do que as instituições devem realizar. Monteiro (2003) afirma que há comportamentos característicos das organizações que indicam não terem compreendido que os critérios e os valores notícia são fundamentais para a construção da notícia, pois a produção de notícia apresenta um caráter intencional e negociado, como a publicação de matérias que atendem as necessidades organizacionais. Desse modo, o referencial teórico deste trabalho terá como eixo a teoria de Newsmaking.

O Newsmaking trata da produção de informação, ou seja, volta-se para os estudos sobre o produtor da mensagem, com foco nas rotinas de trabalho que transformam o fato em notícia. Isto é, examina a rotina de produção da notícia e os critérios que definem a informação que será veiculada nos meios de comunicação.

A noticiabilidade é uma das práticas presentes na teoria do newsmaking e corresponde ao conjunto de critérios, operações e instrumentos com os "quais os aparatos de informação enfrentam a tarefa de escolher, cotidianamente, de número imprevisível e indefinido de acontecimentos, uma quantidade finita e tendenciavelmente estável de notícia" (WOLF, 2003, p. 196). Já os valores-notícia são definidos como conjunto de elementos e princípios utilizados para caracterizar os acontecimentos que são significativos e interessantes. De acordo com Wolf(2003) e Hohlfeldt (2001), os valoresnotícia estão agrupados em cinco categorias que são: 1) critérios substantivos da notícia

\section{Revista ALTERJOR}

Grupo de Estudos Alterjor: Jornalismo Popular e Alternativo (ECA-USP)

Ano 11 - Volume 02 - Edição 24 - Julho-Dezembro de 2021 Av. Professor Lúcio Martins Rodrigues, 443, Cidade Universitária, São Paulo, CEP: 05508-020 


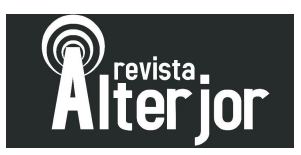

relacionados ao seu conteúdo e seus personagens, 2) disponibilidade de materiais e categorias relativas ao produto informativo, 3) categorias relativas ao meio de informação, 4) categorias relativas ao público e 5) categorias relativas à concorrência.

\section{COMUNICAÇÃO INSTITUCIONAL}

A comunicação, como processo de troca de informações, está presente nas instituições, se comunicam com seu público interno e externo. Para Kunsch (2003), a comunicação institucional é a responsável pela construção da imagem e identidade corporativa positiva para uma organização, que permite à instituição ter um conceito e um posicionamento favorável diante da opinião pública. Torquato (1986) e Kunsch (2003, p. 172) delineiam que a identidade corporativa refere-se aos valores básicos e às características atribuídos a uma organização, bem como reflete e projeta a real personalidade, evidenciando o que é uma organização.

Fonseca (1999 apud Kunsch, 2003, p. 164) define comunicação institucional como um elemento de difusão de informações de interesse público sobre as filosofias, as políticas, as práticas e os objetivos das organizações. Esta comunicação, por meio das relações públicas, realça os atributos relacionados com a missão, a visão, os valores e a filosofia da organização, além de contribuir para o desenvolvimento do subsistema institucional.

Kunsch (2003) afirma que a comunicação institucional implica conhecer e compartilhar a identidade corporativa da organização. Assim, a autora propõe que a instituição utilize estratégicas e políticas de comunicação bem planejadas e definidas pela área de relações públicas. Dessa forma, a instituição planeja a comunicação numa perspectiva de comunicação integrada. No entanto, isso não é uma tarefa fácil, pois a instituição deve elaborar estratégias que possibilitam a sinergia das diversas áreas da comunicação organizacional. Assim, as publicações institucionais são uma das ferramentas de comunicação utilizadas e desenvolvidas pela organização para relacionarse com seus públicos.

A notícia institucional se insere nas publicações institucionais que, segundo Torquato (1986), projetam uma boa imagem da organização, mostrando sua organização,

\section{Revista ALTERJOR}

Grupo de Estudos Alterjor: Jornalismo Popular e Alternativo (ECA-USP)

Ano 11 - Volume 02 - Edição 24 - Julho-Dezembro de 2021 Av. Professor Lúcio Martins Rodrigues, 443, Cidade Universitária, São Paulo, CEP: 05508-020 


\section{Retiejor}

produtos, qualidade e técnicas. Considerando a notícia como uma ferramenta que amplia a presença das organizações nos meios de comunicação, algumas instituições também produzem notícias, como a Conferência Nacional dos Bispos do Brasil (CNBB), para firmar a identidade da organização no campo em que atuam. Portanto, a notícia institucional tem papel fundamental nas relações públicas internas e externas para promover a visibilidade das organizações. No entanto, mesmo que a instituição promova um acontecimento para o público que considera importante, a notícia institucional também obedece aos critérios da teoria do Newsmaking, pois emprega-se da linguagem jornalística.

\section{PANORAMA DA COMUNICAÇÃO NA IGREJA E A CNBB}

Fruto do Concílio do Vaticano II e um dos documentos mais comentados durante o encontro eclesial, o decreto Inter Mirifica reconhece a relevância da comunicação social e de seus meios para disseminar a doutrina católica.Aprovado na sessão do dia 4 de dezembro de 1963, o decreto chama a atenção para uma formação sobre uso correto dos meios de comunicação e também incentiva a utilização deste instrumento para a ação pastoral das comunidades eclesiais.

Soares (1988), aponta que os principais avanços do Inter Mirifica, em relação a documentos publicados anteriormente pela Igreja, foi reconhecer que a sociedade deve contribuir para a formação das retas opiniões públicas; que a preferência deve se dar livre escolha das informações veiculadas, sem proibição ou qualquer censura; que deve haver formação pessoal do receptor com o direcionamento das formas necessárias para usar os meios de comunicação no campo pastoral e a elevação de categoria dos meios como instrumento de evangelização indispensável para o clero. O documento incentivou também a criação de um Dia Mundial das Comunicações para a instrução do povo no que diz respeito às questões de comunicação.

De acordo com Puntel (2011, p. 223), a Igreja teve sérias dificuldades em assentir os valores positivos presentes nos meios de comunicação. No século XV, a Igreja enfrentava a criação da imprensa porque as mudanças eram assimiladas pela sociedade. O período é marcado pela inquisição, fase em que a "Igreja é a intermediária entre a

\section{Revista ALTERJOR}

Grupo de Estudos Alterjor: Jornalismo Popular e Alternativo (ECA-USP)

Ano 11 - Volume 02 - Edição 24 - Julho-Dezembro de 2021 Av. Professor Lúcio Martins Rodrigues, 443, Cidade Universitária, São Paulo, CEP: 05508-020 


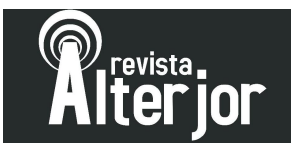

produção do saber e a sua difusão na sociedade". No entanto, o uso do instrumento funcionava "como vias alternativas para difundir sua missão". Assim, a Igreja começou, mesmo de forma lenta e gradual, a notar a serventia dos meios de comunicação na disseminação de suas mensagens.

Promulgada em 23 de maio de 1971, pelo Paulo VI, a instrução pastoral Communio et Progressio, da Comissão Pontifícia para os Meios de Comunicação Social, amplia os avanços do Inter Mirifica. Publicado por mandato do Concílio do Vaticano II, o documento da Igreja reafirma o direito à informação e o direito de informar, assim como também relembra as condições para utilizar os meios de comunicação. A instrução ainda considera as peculiaridades de cada veículo de comunicação, a comunicação social como elemento articulador para a formação da opinião pública dentro da Igreja.

O Communio et Progressio ausculta a sociedade contemporânea, levantando questões sobre a presença dos meios e a comunicação no mundo moderno. Segundo Soares (1988, p. 108), a instrução foi um documento elaborado com a necessidade de dialogar com os profissionais de comunicação social e exortar para o uso destes meios para o progresso humano.

A Igreja demonstrou, ao longo de vários documentos oficiais, seu interesse pelos meios de comunicação. Entretanto, de 1971 a 1989, praticamente não existiram documentos sobre a comunicação. De acordo com Puntel (2001), essa época caracterizase por profundas transformações no campo midiático, em que é possível notar a mudança da era analógica para a era digital. Em 1992, a Comissão Pontifícia para os Meios de Comunicação Social publicou uma nova instrução pastoral chamada Aetatis Novae, que apresenta os princípios e as ideias abordados nos documentos eclesiais anteriores e procura um instrumento de trabalho e de incentivo para as pessoas que encontram dificuldades nas consequências pastorais do uso das comunicações. Para Puntel (2011, p. 231;232), o documento, apesar de não apresentar nenhuma novidade, valoriza os comunicadores e apresenta um subsídio para a Pastoral da Comunicação.

No início dos anos 2000, a Igreja volta-se para a questão ética nas comunicações. O Pontifício Conselho para as Comunicações publica documentos voltados para a ética nas comunicações. No documento, Ética nas comunicações sociais, a Igreja afirma que

\section{Revista ALTERJOR}

Grupo de Estudos Alterjor: Jornalismo Popular e Alternativo (ECA-USP)

Ano 11 - Volume 02 - Edição 24 - Julho-Dezembro de 2021 Av. Professor Lúcio Martins Rodrigues, 443, Cidade Universitária, São Paulo, CEP: 05508-020 


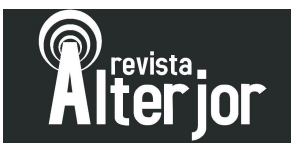

tem motivos próprios para se interessar pelos meios de comunicação social e que a abordagem dessas ferramentas é principalmente positiva. A publicação expõe que a comunicação "deve ser sempre sincera, dado que a verdade é essencial para a liberdade individual e para a autêntica comunidade entre as pessoas" (VATICANO, 2000). Em Igreja e Internet, a Igreja aborda as implicações da internet como instrumento de evangelização, capaz de ultrapassar distâncias e isolamento e alcançar grupos específicos. Já no documento Ética na Internet afirma que a internet é um dos instrumentos de comunicação mais poderosos que deve estar a serviço do bem comum e ajudar a transmitir os valores morais e éticos do clero.

A partir da década de 1940, a Igreja no Brasil passou por um período de transição que mudaria os seus próximos anos. Barros $(2003$, p. 26) aponta os desdobramentos que interviram na renovação da Igreja. Para ele, os mais significativos foram "o vigor do pensamento católico, liderado por leigos, sobre as questões de maior interesse para as elites; a introdução no Brasil de um regime democrático mais moderno, a partir de 1945".

Em 1945, o país vivia a queda do Estado Novo e volta de Getúlio Vargas à presidência da república após oito anos de um governo totalitário. O cenário político do Brasil ingressava em um regime democrático mais moderno. Neste período, no panorama da Igreja, surgiu presença do padre Helder Câmara, um jovem cearense que a partir dos anos 1950 daria início aos os novos rumos da Igreja no País.

Nascido em 1909, padre Helder atuava nas questões de interesse da Igreja, como a renovação do conteúdo, do método e da pedagogia da catequese no Brasil. Segundo Barros (2003), Câmara utilizava como ferramenta dessa renovação a Revista Catequética que era feito por ele. Helder também foi vice-assistente e, posteriormente, assistente geral da Ação Católica Brasileira (ACB).

Durante a década de 1950, o País passara por questões atípicas da realidade brasileira. Em resumo, o contexto político era marcado pela vitória de Getúlio Vargas para presidência da República, que se suicidou em 1954, devido ao governo turbulento. Em 1956, Juscelino Kubitschek assumiu o cargo de presidente, prometendo o desenvolvimento do Brasil com slogan da sua candidatura "50 anos em 5". O clima no País era de otimismo e processo.

\section{Revista ALTERJOR}

Grupo de Estudos Alterjor: Jornalismo Popular e Alternativo (ECA-USP)

Ano 11 - Volume 02 - Edição 24 - Julho-Dezembro de 2021 Av. Professor Lúcio Martins Rodrigues, 443, Cidade Universitária, São Paulo, CEP: 05508-020 


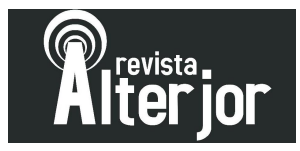

Em termos de Igreja, a intenção de criar a Conferência Nacional dos Bispos do Brasil surgiu a partir de 1950, em um encontro privado com Giovanni Battista, o monsenhor Helder apresentou ao então subsecretário de Estado do Vaticano as grandes linhas do projeto da CNBB. Em outubro de 1951, monsenhor Helder entregou o estatuto provisório da futura Conferência. Em maio do ano seguinte, os cardeais Jaime Barros Câmara e Carlos Carmelo enviaram correspondência a todos os bispos do Brasil convocando-os para assembleia de fundação da instituição.

Nos primeiros anos da Conferência, a Igreja não só se transformava interiormente, como também expandia seus horizontes e estabelecia relações mais profundas com as Igrejas da América Latina e América do Norte. Além disso, a união com Estado em favor do desenvolvimento do País gerou resultados impactantes. Entre eles, uma política de desenvolvimento da região Nordeste, que estava fora do plano de metas do presidente Kubitscheck; a criação do Movimento de Educação de Base (MEB) em 1961 durante o governo de Jânio Quadros, que se destinou à educação de jovens e adultos na região norte, nordeste e centro-oeste do Brasil, e resultou na sindicalização rural. Dom Helder, responsável pela criação da Conferência, contribuiu em várias causas importantes para o País, principalmente no que se refere à CNBB. Atualmente, a entidade é definida como uma instituição permanente que congrega os Bispos da Igreja católica no País.

A CNBB é composta por 18 regionais e atua em diferentes frentes, por meio de comissões episcopais. São elas: para a Vida e a Família; Comunicação Social; Caridade, Justiça e Paz; Pastoral para a Ação Missionária e Cooperação; Animação Bíblico; Pastoral para o Laicato; Pastoral para os Ministérios Ordenados e a Vida Consagrada; Educação e Cultura; Doutrina da Fé; Ecumenismo; Liturgia e Juventude. O conselho atual da entidade é composto pelo presidente dom Walmor Oliveira; vice-presidentes, dom Jaime Spengler e dom Mário Antônio; pelo secretário geral, dom Joel Portella. a sede da instituição fica em Brasília.

A instituição A Conferência dos Bispos do Brasil participou do evento eclesial mais importante do século XX, como afirma o padre Manoel José de Godoy (2003). Para ele, a relação da instituição com o Concílio do Vaticano II é de uma união perfeita que

\section{Revista ALTERJOR}

Grupo de Estudos Alterjor: Jornalismo Popular e Alternativo (ECA-USP)

Ano 11 - Volume 02 - Edição 24 - Julho-Dezembro de 2021 Av. Professor Lúcio Martins Rodrigues, 443, Cidade Universitária, São Paulo, CEP: 05508-020 


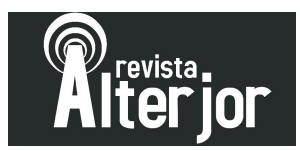

gera frutos rapidamente e amplamente. Para o padre José Oscar Beozzo (2003), o Concílio II foi decisivo para caminhada, consolidação e projeção da Conferência.

Em abril de 1962, a CNBB criou o Plano de Emergência (PE) para atender ao pedido do então papa, João XXIII, que clamava da Igreja Latino-Americana uma "rigorosa e corajosa ação evangelizadora para fazer face à situação do catolicismo nessa região do mundo" (BARROS, 2003, p. 46). Ainda em 1962, a Conferência criou o Secretariado Nacional da Opinião Pública que foi transformado em Setor de Comunicação Social em 1971. A comunicação também foi tema na Campanha da Fraternidade (CF) de 1989, - ação realizada durante o período quaresmal que propõe uma formação de consciência e incentivo à prática da caridade. Com o tema "Fraternidade e Comunicação" e lema "Comunicação para a Verdade e a Paz", a CF de 1989 visava tratar dois aspectos da comunicação: o modo que as pessoas se relacionavam e a comunicação produzida pelos meios de comunicações.

A partir de 1989, a instituição dos bispos passou a versar sobre a comunicação, principalmente para ser indicado como tema central de uma Assembleia Geral da CNBB. Em 1996, o conselho permanente da Conferência definiu que o tema central de 1997 seria “A Igreja e a Comunicação rumo ao novo milênio".

O subsídio, titulado com o mesmo tema da assembleia geral, reuniu as conclusões e os compromissos dos bispos para o ano de 1997. O documento discorre sobre as características e influência da comunicação na Igreja. Nos capítulos, é possível perceber o interesse da Igreja com o fenômeno comunicacional como a comunicação institucional, a formação para o uso dos meios de comunicação e os novos desafios das mídias modernas. Documentos eclesiais ao longo da história da Igreja, o impacto da informação e da ética na comunicação na sociedade, métodos e processos comunicacionais no interior da instituição e orientações para o trabalho pastoral também são expostos no texto.

A CNBB deu passos ainda mais significativos a respeito da comunicação no Brasil, com a aprovação do Diretório de Comunicação da Igreja no Brasil, em 14 de março de 2014. O documento, composto por dez capítulos, aponta novos rumos para a comunicação da Igreja Católica no Brasil e direciona a atuação da Pastoral da Comunicação, destina-se a todos, mas especialmente aos formadores e condutores das

\section{Revista ALTERJOR}

Grupo de Estudos Alterjor: Jornalismo Popular e Alternativo (ECA-USP)

Ano 11 - Volume 02 - Edição 24 - Julho-Dezembro de 2021 Av. Professor Lúcio Martins Rodrigues, 443, Cidade Universitária, São Paulo, CEP: 05508-020 


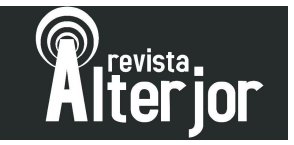

práticas de comunicação em todos os âmbitos eclesiais e nas relações da Igreja com sociedade.

Além desse panorama da relação entre comunicação e a entidade, também há a produção de conteúdo jornalístico da Conferência Nacional dos Bispos do Brasil que se enquadra no campo da comunicação. A redação da CNBB funciona como assessoria de imprensa da entidade e também como produtor de conteúdo em áudio, vídeo e impresso, além de alimentar as notícias no site. A equipe de trabalho é formada por cinco jornalistas: padre Rafael Vieira, assessor e coordenador; Willian Bonfim, coordenador auxiliar; Maurício Sant'Ana, editor, cinegrafista e fotógrafo; e os jornalistas Bruno Feitosa, Larissa Carvalho e Luiz Lopes, além de um menor aprendiz.

A rotina de trabalho consiste em atualizar o site nas segundas, quartas e sextasfeiras, com pautas novas para os seis destaques, localizados na parte superior do novo site da entidade. A redação da CNBB tem parceria com as comissões episcopais, pastorais, regionais e organismos para que as notícias sejam publicadas no site nacional. Geralmente as matérias são resumidas em dois parágrafos, incluindo um link direcionado para o site de origem da matéria.

\section{METODOLOGIA}

Esta monografia tem como arcabouço teórico a teoria do jornalismo denominada Newsmaking que trata da produção de notícias e apresenta os processos que tornam os acontecimentos em informação noticiosa a ser veiculada nos meios de comunicação. Além disso, a literatura é embasada em pesquisas documental e bibliográfica sobre comunicação organizacional e eclesial.

Como metodologia de pesquisa, foram aplicadas a análise de conteúdo, com a finalidade de identificar os valores-notícia das notícias publicadas no site da CNBB. A análise de conteúdo teve seu berço na comunicação. Trata-se de uma técnica de pesquisa que reúne um conjunto de instrumentos metodológicos, aperfeiçoados constantemente, e que faz um estudo dos materiais recolhidos para decodificar a mensagem. Esta metodologia foi progredindo ao longo do tempo, como a inserção do computador. Para Bardim (1977, p. 44), o atual conceito de análise de conteúdo é:

\section{Revista ALTERJOR}

Grupo de Estudos Alterjor: Jornalismo Popular e Alternativo (ECA-USP)

Ano 11 - Volume 02 - Edição 24 - Julho-Dezembro de 2021 Av. Professor Lúcio Martins Rodrigues, 443, Cidade Universitária, São Paulo, CEP: 05508-020 
Um conjunto de técnicas de análise das comunicações visando obter por procedimentos sistemáticos e objectivos de descrição do conteúdo das mensagens indicadores (quantitativos ou não) que permitam a inferência de conhecimentos relativos às condições de produção/ recepção (variáveis inferidas) destas mensagens.

Desse modo, segundo Bardin (1977), este método de pesquisa abrange as ações de explicitação, sistematização do conteúdo das mensagens, bem como a expressão deste conteúdo, com o intuito de se efetuar deduções lógicas e justificadas sobre a origem das mensagens, como quem as emitiu, em que contexto e quais efeitos. A análise de conteúdo tem como objetivos a superação da incerteza e o enriquecimento da leitura.

Herscovitz (2007, p. 127) aprofunda o conceito de análise de conteúdo no campo do jornalismo.

\begin{abstract}
Análise de conteúdo jornalístico: método de pesquisa que recolhe e analisa textos, sons, símbolos e imagens impressas, gravadas ou veiculadas em forma eletrônica ou digital encontrados na mídia a partir de uma amostra aleatória ou não dos objetos estudados com o objetivo de fazer inferências sobre seus conteúdos e formatos enquadrando-os em categorias previamente testadas, mutuamente exclusivas e passíveis de replicação.
\end{abstract}

A análise de conteúdo é dividida em três fases cronológicas. A primeira fase é a pré-análise que trata de "um período de instituições, mas tem como objetivo tornar operações e sistematizar as ideias iniciais, de maneira a conduzir um esquema preciso do desenvolvimento das operações sucessivas" (BARDIN, 1977, p. 121). Esta fase visa a escolha dos documentos, a formulação das hipóteses e dos objetivos, como apresentado na introdução. A segunda fase trata da exploração do material, das escolhas das unidades, as regras de contagem e a escolha das categorias, ou seja, operações de codificação. Por fim, a terceira fase refere-se ao tratamento dos resultados obtidos e à interpretação

De acordo com Herscovitz (2007), a identificação sistemática de tendências e representações possui melhores resultados quando se emprega a análise de conteúdo quantitativa, que se refere à contagem de frequência do conteúdo, e a análise qualitativa, que é uma avaliação do conteúdo de modo geral, apresentando o contexto no qual aparece, os meios que veicula e quais públicos se destina.

\title{
Revista ALTERJOR
}

Grupo de Estudos Alterjor: Jornalismo Popular e Alternativo (ECA-USP)

Ano 11 - Volume 02 - Edição 24 - Julho-Dezembro de 2021 Av. Professor Lúcio Martins Rodrigues, 443, Cidade Universitária, São Paulo, CEP: 05508-020 


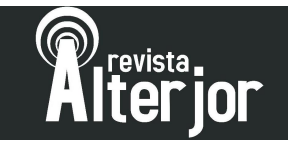

Bardin (1977) apresenta diferentes tipos de análise de conteúdo. Neste trabalho será aplicada a análise de conteúdo categorial. A análise de conteúdo categorial constituise de "desmembramentos do texto em unidades, em categorias segundo reagrupamentos analógicos” (BARDIN, 1977, p. 199). Assim, nesta monografia será feita uma análise de conteúdo de notícias do site da CNBB, que serão identificadas, por meio de categorias, com o propósito de identificar os valores-notícia da instituição.

O período de análise abrange três meses de publicações de notícias no site da Conferência, de março a maio de 2017, visto que dois grandes eventos ligados à Igreja Católica aconteceram em meados da data escolhida: a Campanha da Fraternidade e a Assembleia Geral da CNBB. Ambos os acontecimentos são importantes para a instituição, uma vez que a CNBB é responsável por elaborar e organizar a Campanha da Fraternidade, enquanto a Assembleia Geral é o momento que reúne todo o episcopado brasileiro, com o objetivo de discutir questões importantes para a Igreja. O corpus desta pesquisa compreende 44 matérias que estão disponíveis no site, selecionadas a partir do método da Semana Artificial. Esta técnica pode ser por quinzena ou mês artificial. Segundo Bauer (2000 apud Herscovitz, 2007, p. 131), a amostra constitui-se da seleção de cada dia de uma semana distinta: a primeira semana será representada pela segundafeira; a segunda semana, pela terça; a terceira, pela quarta, e assim sucessivamente. Esta técnica serve para obter uma amostra variada com menos distorções possíveis.

Pretende-se analisar as notícias da instituição, buscando classificá-las em uma tabela, inicialmente, a partir das abrangências geográficas dos fatos, conforme a própria CNBB utiliza em seu site: regionais, nacionais e internacionais. A partir desta classificação, usa-se palavras-chave das notícias para estabelecer os valores-notícia presentes nos acontecimentos noticiados pela CNBB. O recorte feito pela palavras-chaves tem como critério diferenciar os temas para escolher as categorias das notícias, para posteriormente determinar os valores- notícia da Conferência Nacional dos Bispos do Brasil.

Para Johan Galtung (1999) e Holmboe Ruge (1999), o acontecimento para se tornar notícia precisa passar por uma seleção de fatores, já que não é possível registrar

\section{Revista ALTERJOR}

Grupo de Estudos Alterjor: Jornalismo Popular e Alternativo (ECA-USP)

Ano 11 - Volume 02 - Edição 24 - Julho-Dezembro de 2021 Av. Professor Lúcio Martins Rodrigues, 443, Cidade Universitária, São Paulo, CEP: 05508-020 


\section{Anteier}

tudo como notícia. Alguns desses fatores são a frequência, inequivocidade, significância e proximidade cultural, personificação, e referência a algo negativo.

A frequência trata de "quanto mais a frequência do acontecimento se assemelhar à frequência do meio noticioso, mais hipóteses existem de ser registrado como notícia por esse mesmo meio noticioso" (GALTUNG; RUGE, 1999, p. 64). A inequivocidade consiste na clareza do acontecimento, ou seja, menos ambiguidades no seu significado. Já a significância e proximidade cultural tem a ver com o semelhante culturalmente e a relevância. O indivíduo dará mais atenção ao que é familiar ao invés de algo distante. A personificação refere-se às nações de elite ou pessoas que são instrumentos ou causam os acontecimentos. E por fim, o fator negativo corresponde ao critério de frequência e inequivocidade, pois o negativo leva menos tempo e é mais fácil de ser encontrado e também apresenta clareza e não ambiguidades na sua interpretação.

O desafio da pesquisa baseia-se principalmente na mudança do site da instituição, no dia 26 de abril, início da Assembleia da CNBB. No antigo site, as notícias eram classificadas visivelmente por imprensa, pastorais, organismos, regionais e comissões. Já no novo site as notícias são publicadas com essas mesmas classificações, porém de um

modo mais geral, além de ser interativo e organizado, também apresenta fotos mais atrativas.

\section{PESQUISA EMPÍRICA: AMOSTRA}

Nesta pesquisa, a análise total de 44 matérias tem como objetivo identificar os valores-notícia da CNBB. As matérias selecionadas vão desde o início de março até final de maio de 2017, estabelecidas de acordo com o método da Semana Artificial apresentada por Herscovitz (2007).

Os valores-notícia são essenciais na produção do conteúdo jornalístico dos veículos e também na produção de conteúdos institucionais das entidades. Os valoresnotícia compõem somente uma parte dos critérios de noticiabilidade, que abrange algo maior. Em resumo, valores-notícia são utilizados para designar as qualidades dos fatos, isto é, as características que os tornam noticiáveis.

\section{Revista ALTERJOR}

Grupo de Estudos Alterjor: Jornalismo Popular e Alternativo (ECA-USP)

Ano 11 - Volume 02 - Edição 24 - Julho-Dezembro de 2021 Av. Professor Lúcio Martins Rodrigues, 443, Cidade Universitária, São Paulo, CEP: 05508-020 


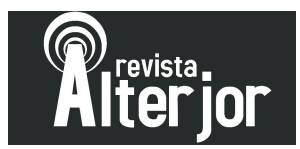

No caso das notícias veiculadas no site da CNBB, tabelas foram criadas para identificar os valores-notícia que apareceram no período da análise estabelecida. A partir dos dados analisados na tabela 1 , nota-se que a maioria das matérias foram publicadas no mês de abril e maio, período da Assembleia Geral da CNBB.

Quadro 1 - Corpus de pesquisa (44 matérias)

\begin{tabular}{|c|c|c|c|c|c|c|}
\hline \multicolumn{7}{|c|}{ BASEADA EM 44 MATÉRIAS POR DATAS } \\
\hline \multirow{2}{*}{ MÊS } & \multirow{2}{*}{ DATA } & \multirow{2}{*}{ TÍTULO/ CHAMADA DAS MATÉRIA } & \multicolumn{3}{|c|}{ ABRANGÊNCIA } & \multirow{2}{*}{$\begin{array}{l}N^{\circ} \text { DE } \\
\text { PUBLIC } \\
\text { AÇÕES } \\
\text { POR } \\
\text { DIA }\end{array}$} \\
\hline & & & $\begin{array}{l}\text { INTERNACI } \\
\text { ONAL }\end{array}$ & NACIONAL & $\underset{\mathrm{L}}{\mathrm{REGIONA}}$ & \\
\hline \multirow{8}{*}{ MARÇO } & $01 / 03 / 2017$ & $\begin{array}{l}\text { "Admirar os biomas é contemplar a obra do } \\
\text { criador", afirma cardeal Sergio da Rocha }\end{array}$ & & $x$ & & 1 \\
\hline & $09 / 03 / 2017$ & $\begin{array}{l}\text { Setor Litúrgico apoia criação de } \\
\text { especialização em "Espaço Litúrgico: } \\
\text { Arquitetura e Arte Sacra" }\end{array}$ & & $\mathrm{X}$ & & \multirow[t]{2}{*}{2} \\
\hline & $09 / 03 / 2017$ & $\begin{array}{l}\text { Comissão prepara Guia de Acolhida para } \\
\text { Estudantes Estrangeiros }\end{array}$ & & $\mathrm{x}$ & & \\
\hline & $17 / 03 / 2017$ & $\begin{array}{l}\text { Comunidade na sede da CNBB realiza } \\
\text { momento penitencial " } 24 \text { horas para o } \\
\text { Senhor" }\end{array}$ & & & $\mathrm{x}$ & \multirow[t]{2}{*}{2} \\
\hline & $17 / 03 / 2017$ & $\begin{array}{l}\text { Anuário Católico: nota de esclarecimento do } \\
\text { Ceris }\end{array}$ & & $\mathrm{x}$ & & \\
\hline & $25 / 03 / 2017$ & & & & & 0 \\
\hline & $26 / 03 / 2017$ & $\begin{array}{l}\text { Ex-vice-presidente da CNBB faleceu aos } 88 \\
\text { anos de idade em Recife (PE) }\end{array}$ & & $x$ & & \multirow{2}{*}{2} \\
\hline & $26 / 03 / 2017$ & $\begin{array}{l}\text { CNBB envia mensagem de condolências pelo } \\
\text { falecimento de dom Marcelo Carvalheira }\end{array}$ & & $\mathrm{x}$ & & \\
\hline \multirow{8}{*}{ ABRIL } & $03 / 04 / 2017$ & $\begin{array}{l}\text { Material apresenta pronunciamentos sobre } \\
\text { Reforma da Previdência }\end{array}$ & & $\mathrm{x}$ & & 1 \\
\hline & $11 / 04 / 2017$ & & & & & 0 \\
\hline & $19 / 04 / 2017$ & $\begin{array}{l}\text { Nomeados bispos para Imperatriz (MA) e } \\
\text { Joinville (SC) }\end{array}$ & & $\mathrm{x}$ & & \multirow{4}{*}{4} \\
\hline & $19 / 04 / 2017$ & $\begin{array}{l}\text { Papa Francisco nomeia bispos para } \\
\text { Itacoatiara (AM) e Campo Mourão (PR) }\end{array}$ & & $\mathrm{x}$ & & \\
\hline & $19 / 04 / 2017$ & $\begin{array}{l}\text { Vaticano emite nota de esclarecimento sobre } \\
\text { carta do Papa a Michel Temer }\end{array}$ & $x$ & & & \\
\hline & $19 / 04 / 2017$ & $\begin{array}{l}\text { Reforma da Previdência: CNBB, OAB e } \\
\text { Conselho Federal de Economia reiteram } \\
\text { posição em nota conjunta }\end{array}$ & & $\mathrm{x}$ & & \\
\hline & $27 / 04 / 2017$ & $\begin{array}{l}\text { Mensagem da CNBB aos trabalhadores (as) } \\
\text { do Brasil: "O dia do trabalhador é celebrado } \\
\text { em meio a um ataque aos direitos } \\
\text { conquistados" }\end{array}$ & & $\mathrm{x}$ & & \multirow{2}{*}{16} \\
\hline & $27 / 04 / 2017$ & $\begin{array}{l}\text { Dom Geraldo Lyrio: "A posição da Igreja não } \\
\text { é de tomar como bandeira sua, alguma } \\
\text { bandeira defendida por este ou por aquele } \\
\text { grupo" }\end{array}$ & & $\mathrm{x}$ & & \\
\hline
\end{tabular}

\section{Revista ALTERJOR}

Grupo de Estudos Alterjor: Jornalismo Popular e Alternativo (ECA-USP)

Ano 11 - Volume 02 - Edição 24 - Julho-Dezembro de 2021 


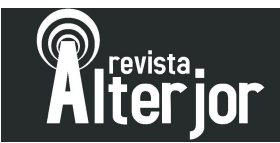

\begin{tabular}{|c|c|c|c|c|c|c|}
\hline & $27 / 04 / 2017$ & \begin{tabular}{|l} 
Cardeal Odilo Pedro Scherer: "O povo tem \\
direito de se manifestar, de pedir \\
esclarecimentos"
\end{tabular} & & $x$ & & \\
\hline & $27 / 04 / 2017$ & $\begin{array}{l}\text { Dom Esmeraldo Barreto: "estávamos vivendo } \\
\text { e continuamos vivendo uma mudança de } \\
\text { época" }\end{array}$ & & $x$ & & \\
\hline & $27 / 04 / 2017$ & $\begin{array}{l}\text { Núncio Apostólico no Brasil celebra missa na } \\
\text { Assembleia dos bispos e fala sobre } \\
\text { testemunho }\end{array}$ & & $x$ & & \\
\hline & $27 / 04 / 2017$ & $\begin{array}{l}\text { Pastoral do Menor: "Dê Oportunidade. Faça } \\
\text { diferente, ninguém nasce infrator" }\end{array}$ & & & $x$ & \\
\hline & $27 / 04 / 2017$ & $\begin{array}{l}\text { Pastorais Sociais realizaram encontro } \\
\text { regional em Guarapuava (PR) }\end{array}$ & & & $x$ & \\
\hline & $27 / 04 / 2017$ & $\begin{array}{l}\text { Bispos novos são apresentados na } 55^{a} \\
\text { Assembleia Geral da CNBB }\end{array}$ & & $x$ & & \\
\hline & $27 / 04 / 2017$ & $\begin{array}{l}\text { Oração dos Bispos do Regional Centro-Oeste } \\
\text { da CNBB pelo atual momento do Brasil }\end{array}$ & & & $x$ & \\
\hline & $27 / 04 / 2017$ & $\begin{array}{l}\text { Dia do Trabalhador: Pastoral Operária } \\
\text { divulga nota }\end{array}$ & & $x$ & & \\
\hline & $27 / 04 / 2017$ & $\begin{array}{l}\text { Estadão conteúdo: "D. Leonardo espera que } \\
\text { a greve geral seja pacífica e sem violência" }\end{array}$ & & $x$ & & \\
\hline & $27 / 04 / 2017$ & $\begin{array}{l}\text { Centro Pe. Vitor Coelho de Almeida, espaço } \\
\text { multiuso, recebe bispos de todo o Brasil }\end{array}$ & & $x$ & & \\
\hline & $27 / 04 / 2017$ & $\begin{array}{l}\text { Dom Leomar: "a grande preocupação é } \\
\text { formar discípulos e não adeptos do } \\
\text { cristianismo" }\end{array}$ & & $x$ & & \\
\hline & $27 / 04 / 2017$ & $\begin{array}{l}\text { Dom João Justino: "Reformas pecam por não } \\
\text { constituírem projeto consistente" }\end{array}$ & & $x$ & & \\
\hline & $27 / 04 / 2017$ & $\begin{array}{l}\text { Dom Peruzzo: "Retomar a reflexão é } \\
\text { fundamental para manter vivos os projetos } \\
\text { urgentes" }\end{array}$ & & $x$ & & \\
\hline & $27 / 04 / 2017$ & $\begin{array}{l}\text { Dom Joel Portella: "o mundo está vivendo } \\
\text { aceleração muito rápida e a crise das } \\
\text { mediações" }\end{array}$ & & $x$ & & \\
\hline \multirow{11}{*}{ MAIO } & $05 / 05 / 2017$ & $\begin{array}{l}\text { Presidente da CNBB celebra missa de } \\
\text { encerramento da } 55^{\mathrm{a}} \text { Assembleia Geral }\end{array}$ & & $x$ & & \multirow{3}{*}{3} \\
\hline & $05 / 05 / 2017$ & $\begin{array}{l}\text { Encerrada a } 55^{a} \text { Assembleia dos bispos da } \\
\text { CNBB realizada em Aparecida (SP) }\end{array}$ & & $x$ & & \\
\hline & $05 / 05 / 2017$ & $\begin{array}{l}\text { Quais os próximos passos do tema "Iniciação } \\
\text { à vida cristã"? Dom Rixen responde }\end{array}$ & & $x$ & & \\
\hline & $13 / 05 / 2017$ & $\begin{array}{l}\text { Balanço final da } 36^{\mathrm{a}} \text { Assembleia Ordinária do } \\
\text { Celam realizada em El Salvador }\end{array}$ & $x$ & & & 1 \\
\hline & $14 / 05 / 2017$ & & & & & 0 \\
\hline & $22 / 05 / 2017$ & $\begin{array}{l}\text { II Encontro da Vida Consagrada Monástica e } \\
\text { Contemplativa começa na quarta }\end{array}$ & & $x$ & & \multirow{5}{*}{5} \\
\hline & $22 / 05 / 2017$ & $\begin{array}{l}\text { Carta do Conic sobre a Semana de Oração } \\
\text { pela Unidade Cristã propõe uma união mais } \\
\text { plena }\end{array}$ & & $x$ & & \\
\hline & $22 / 05 / 2017$ & $\begin{array}{l}\text { Coleção propõe preservação do patrimônio } \\
\text { religioso da Igreja no Brasil }\end{array}$ & & $x$ & & \\
\hline & $22 / 05 / 2017$ & $\begin{array}{l}\text { Futebol, fé e o bispo jogador: confira } \\
\text { reflexões sobre o esporte mais apreciado no } \\
\text { Brasil }\end{array}$ & & $x$ & & \\
\hline & $22 / 05 / 2017$ & $\begin{array}{l}\text { Os cinco novos cardeais criados pelo papa } \\
\text { Francisco segundo profo Fernando Altemeyer }\end{array}$ & $x$ & & & \\
\hline & $30 / 05 / 2017$ & $\begin{array}{l}\text { Seminário Laudato Si' reúne lideranças do } \\
\text { Xingu }\end{array}$ & & & $x$ & 7 \\
\hline
\end{tabular}

\section{Revista ALTERJOR}

Grupo de Estudos Alterjor: Jornalismo Popular e Alternativo (ECA-USP)

Ano 11 - Volume 02 - Edição 24 - Julho-Dezembro de 2021 


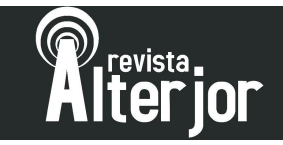

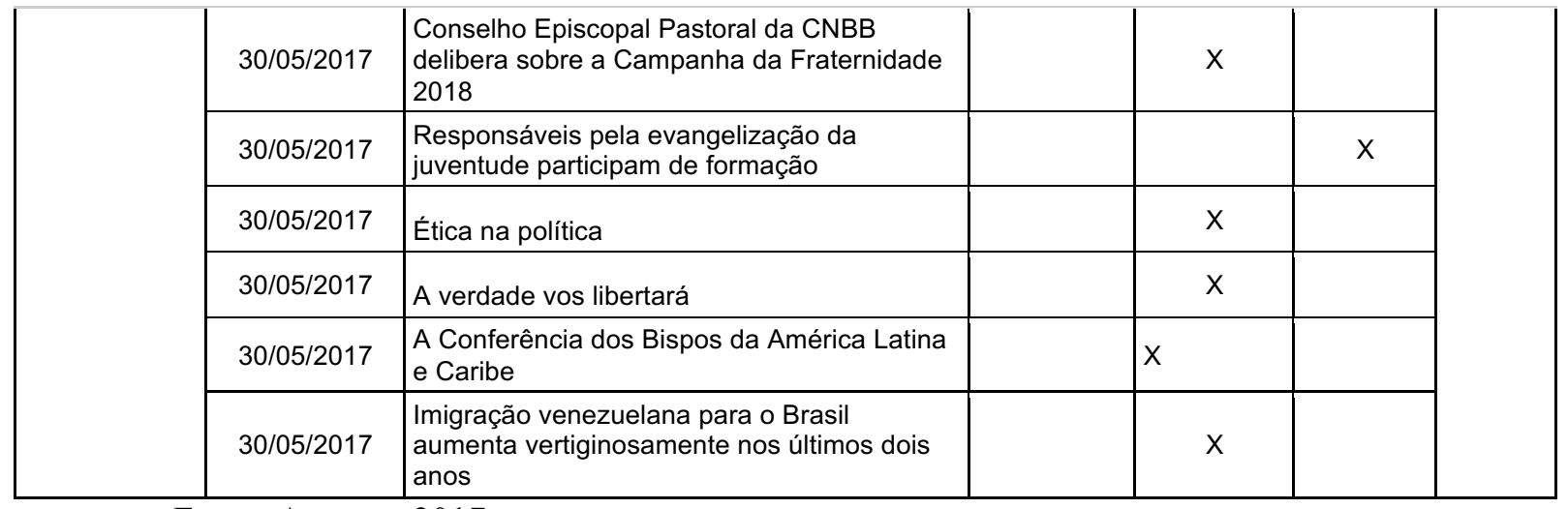

Fonte: Autores, 2017

Neste ano, o tema central da Assembleia foi "Iniciação à Vida Cristã". Embora a Assembleia aborde um tema central, são tratados diversos outros assuntos referentes à atuação da Igreja Católica no Brasil. Já a Campanha da Fraternidade dedica-se somente a um tema. A última edição da campanha abordou "Fraternidade: biomas brasileiros e defesa da vida". Teve como lema "Cultivar e guardar a criação". Ressalta-se, ainda, que esses três meses de análise também abordam outros acontecimentos.

Como é possível observar, em abril foi registrado o número de vinte e uma notícias e em maio, dezesseis. Enquanto isso, em março houve um número pequeno de publicações, somente sete matérias. Também observa-se que um dia de cada mês não houve nenhuma publicação, datadas em 25 de março, 11 de abril e 14 de maio. Dia 11 de abril foi uma terça-feira que talvez não havia nenhuma demanda de produção de notícia para este dia, já as outras datas não tiveram publicações por ser final de semana.

\section{Gráfico 1 - Número de Publicação de notícias por dia}

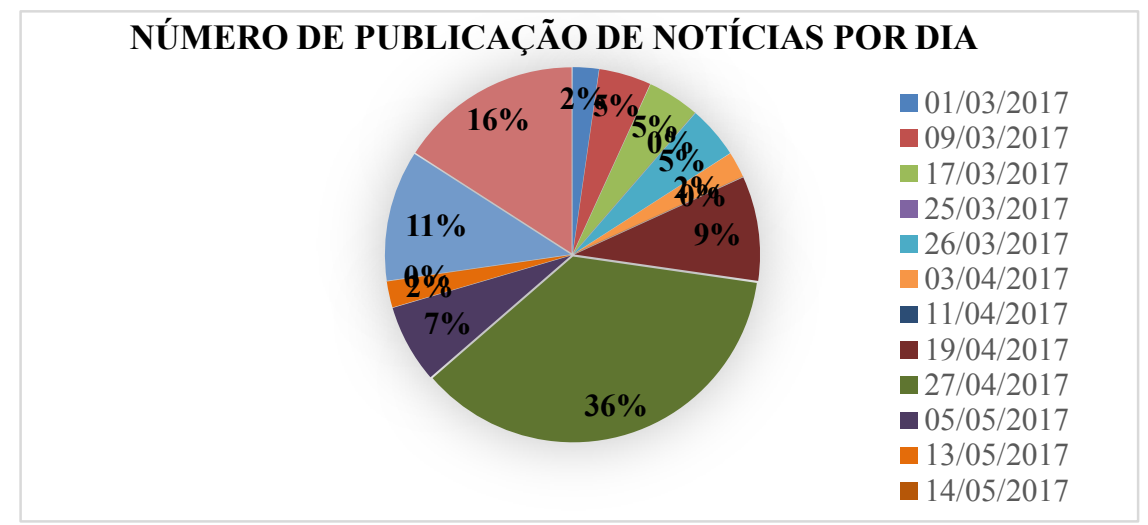

Fonte: Autores

\section{Revista ALTERJOR}

Grupo de Estudos Alterjor: Jornalismo Popular e Alternativo (ECA-USP)

Ano 11 - Volume 02 - Edição 24 - Julho-Dezembro de 2021 


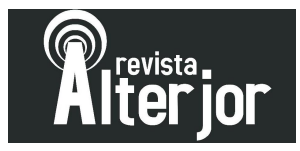

Ao analisar as datas, percebe-se que em 27 de abril foram veiculadas dezesseis matérias, registrando o maior número de notícias em um único dia. A data é marcada pela mensagem da instituição aos trabalhadores, que estavam organizando uma manifestação nacional para o Dia do Trabalhador. Na ocasião, período da 55ª Assembleia Geral, alguns bispos opinaram sobre os direitos dos trabalhadores e sobre situação atual do Brasil, resultando em um número elevado de publicações no site da CNBB.

Dentre as 44 matérias analisadas, três textos são de abrangência internacional, e dizem respeito à hierarquia da Igreja Católica, com foco nas decisões do papa Francisco no Vaticano e na assembleia do Conselho Episcopal Latino-Americano (Celam). As matérias internacionais geralmente são reproduzidas ou adaptadas, pois citam outras fontes de informação como no texto "Balanço Geral da 36a Assembleia Ordinária do Celam realizada em El Salvador", publicado dia 13 de maio de 2017. A matéria cita a fonte Comunicacion Celam e informa que foi traduzida pelo Google Tradutor e alterada pela assessoria de imprensa da instituição.

Já no âmbito nacional, encontram-se 35 dos 44 textos veiculados no site da CNBB, uma vez que a entidade preza pelos assuntos nacionais. As notícias tratavam dos acontecimentos do país e temas reflexivos importantes para toda a nação, principalmente para os católicos, além de reuniões e celebrações vinculados ao episcopado e, suas áreas de atuação. Em regional, os textos voltaram-se para os eventos formativos e encontros realizados por pastorais, comissões ou conselhos. Os seis textos, na maioria das vezes, abordaram a temática social, como a campanha de oportunidade aos menores infratores, "Pastoral do Menor: 'Dê Oportunidade. Faça diferente, ninguém nasce infrator"”, publicada em 27 de abril de 2017.

Na tabela 2, as notícias estão organizadas por título e, a partir da leitura de cada matéria, foram identificadas e registradas palavras-chave, o que permitiu criar categorias de análise. Também na tabela 2, foram apontados os tipos de mídia e links que fazem parte de cada texto noticioso.

\section{Revista ALTERJOR}

Grupo de Estudos Alterjor: Jornalismo Popular e Alternativo (ECA-USP)

Ano 11 - Volume 02 - Edição 24 - Julho-Dezembro de 2021 Av. Professor Lúcio Martins Rodrigues, 443, Cidade Universitária, São Paulo, CEP: 05508-020 
Quadro 2 - Análise das matérias por palavra-chave e tipo de mídia

\begin{tabular}{|c|c|c|c|c|}
\hline \multirow[b]{2}{*}{ TÍTULO/ CHAMADA DAS MATÉRIA } & \multirow[b]{2}{*}{ PALAVRAS-CHAVE } & \multicolumn{3}{|c|}{ TIPO DE MÍDIA } \\
\hline & & FOTO & VÍDEO & \begin{tabular}{|c} 
LINK \\
DIR \\
ECI \\
ONA \\
DO
\end{tabular} \\
\hline $\begin{array}{l}\text { "Admirar os biomas é contemplar a obra do criador", afirma } \\
\text { cardeal Sergio da Rocha }\end{array}$ & $\begin{array}{l}\text { Meio-ambiete, biomas, campanha da } \\
\text { fraternidade }\end{array}$ & $x$ & & $x$ \\
\hline $\begin{array}{l}\text { Setor Litúrgico apoia criação de especialização em "Espaço } \\
\text { Litúrgico: Arquitetura e Arte Sacra" }\end{array}$ & Liturgia, educação, arquitetura, arte sacra & $x$ & & $\mathrm{X}$ \\
\hline $\begin{array}{l}\text { Comissão prepara Guia de Acolhida para Estudantes } \\
\text { Estrangeiros }\end{array}$ & $\begin{array}{l}\text { Educação, guia, cultura, estudantes } \\
\text { estrangeiros, turismo }\end{array}$ & $x$ & & \\
\hline $\begin{array}{l}\text { Comunidade na sede da CNBB realiza momento penitencial " } 24 \\
\text { horas para o Senhor" }\end{array}$ & Celebração, quaresma, penitência & $x$ & & \\
\hline Anuário Católico: nota de esclarecimento do Ceris & Alerta, golpe & $x$ & & \\
\hline $\begin{array}{l}\text { Ex-vice-presidente da CNBB faleceu aos } 88 \text { anos de idade em } \\
\text { Recife (PE) }\end{array}$ & Episcopado, morte & & & \\
\hline $\begin{array}{l}\text { CNBB envia mensagem de condolências pelo falecimento de } \\
\text { dom Marcelo Carvalheira }\end{array}$ & Nota, falecimento & & & \\
\hline $\begin{array}{l}\text { Material apresenta pronunciamentos sobre Reforma da } \\
\text { Previdência }\end{array}$ & $\begin{array}{l}\text { Política, reforma da previdência, corrupção, } \\
\text { exclusão social }\end{array}$ & $x$ & & $\mathrm{x}$ \\
\hline Nomeados bispos para Imperatriz (MA) e Joinville (SC) & Episcopado, Nomeação & $\mathrm{X}$ & & \\
\hline $\begin{array}{l}\text { Papa Francisco nomeia bispos para Itacoatiara (AM) e Campo } \\
\text { Mourão (PR) }\end{array}$ & Episcopado, nomeação & $x$ & & \\
\hline $\begin{array}{l}\text { Vaticano emite nota de esclarecimento sobre carta do Papa a } \\
\text { Michel Temer }\end{array}$ & Vaticano, política, carta, Michel Temer & $x$ & & \\
\hline $\begin{array}{l}\text { Reforma da Previdência: CNBB, OAB e Conselho Federal de } \\
\text { Economia reiteram posição em nota conjunta }\end{array}$ & $\begin{array}{l}\begin{array}{c}\text { Política, reforma da previdência, trabalhadores, } \\
\text { direitos }\end{array} \\
\end{array}$ & $x$ & & \\
\hline $\begin{array}{l}\text { Mensagem da CNBB aos trabalhadores (as) do Brasil: "O dia do } \\
\text { trabalhador é celebrado em meio a um ataque aos direitos } \\
\text { conquistados" }\end{array}$ & política, social, trabalhador & $x$ & & \\
\hline $\begin{array}{l}\text { Dom Geraldo Lyrio: "A posição da Igreja não é de tomar como } \\
\text { bandeira sua, alguma bandeira defendida por este ou por } \\
\text { aquele grupo" }\end{array}$ & Política, corrupção, ficha limpa & $x$ & & \\
\hline $\begin{array}{l}\text { Cardeal Odilo Pedro Scherer: "O povo tem direito de se } \\
\text { manifestar, de pedir esclarecimentos" }\end{array}$ & $\begin{array}{l}\text { Política, social, reforma trabalhista, } \\
\text { previdência, greve, manifestação }\end{array}$ & $x$ & & \\
\hline $\begin{array}{l}\text { Dom Esmeraldo Barreto: "estávamos vivendo e continuamos } \\
\text { vivendo uma mudança de época" }\end{array}$ & Conferência de Aparecida, missão, assembleia & $\mathrm{X}$ & & \\
\hline $\begin{array}{l}\text { Núncio Apostólico no Brasil celebra missa na Assembleia dos } \\
\text { bispos e fala sobre testemunho }\end{array}$ & Celebração, assembleia, testemunho, Cristo & $x$ & & \\
\hline $\begin{array}{l}\text { Pastoral do Menor: "Dê Oportunidade. Faça diferente, ninguém } \\
\text { nasce infrator" }\end{array}$ & $\begin{array}{c}\text { Infrator, campanha, medida socioeducativa, } \\
\text { adolescentes }\end{array}$ & $\mathrm{X}$ & & $x$ \\
\hline $\begin{array}{l}\text { Pastorais Sociais realizaram encontro regional em Guarapuava } \\
\text { (PR) }\end{array}$ & Pastorais sociais, agentes, desafios & $x$ & & $\mathrm{x}$ \\
\hline $\begin{array}{l}\text { Bispos novos são apresentados na } 55^{a} \text { Assembleia Geral da } \\
\text { CNBB }\end{array}$ & Episcopado, assembleia, nomeação & $x$ & & \\
\hline $\begin{array}{l}\text { Oração dos Bispos do Regional Centro-Oeste da CNBB pelo } \\
\text { atual momento do Brasil }\end{array}$ & $\begin{array}{c}\text { Oração, campanha da fraternidade, corrupção, } \\
\text { reforma política }\end{array}$ & $x$ & & \\
\hline Dia do Trabalhador: Pastoral Operária divulga nota & Reforma, trabalhadores, Michel Temer, direitos & $x$ & & \\
\hline $\begin{array}{l}\text { Estadão conteúdo: "D. Leonardo espera que a greve geral seja } \\
\text { pacífica e sem violência" }\end{array}$ & $\begin{array}{c}\text { Reforma, greve, Michel Temer, assembleia, } \\
\text { trabalhadores }\end{array}$ & \begin{tabular}{|c|c|} 
\\
quadro \\
cinza
\end{tabular} & & \\
\hline $\begin{array}{l}\text { Centro Pe. Vitor Coelho de Almeida, espaço multiuso, recebe } \\
\text { bispos de todo o Brasil }\end{array}$ & Assembleia, estrutura & $x$ & & \\
\hline
\end{tabular}




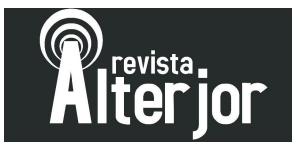

\begin{tabular}{|c|c|c|c|}
\hline $\begin{array}{l}\text { Dom Leomar: "a grande preocupação é formar discípulos e não } \\
\text { adeptos do cristianismo" }\end{array}$ & $\begin{array}{c}\text { Assembleia, vida cristã, catequese, Concílio do } \\
\text { Vaticano II, conversão pastoral }\end{array}$ & $\mathrm{X}$ & $\mathrm{X}$ \\
\hline $\begin{array}{l}\text { Dom João Justino: "Reformas pecam por não constituírem } \\
\text { projeto consistente" }\end{array}$ & $\begin{array}{l}\text { Educação, reforma política, professor, } \\
\text { assembleia }\end{array}$ & $\mathrm{X}$ & \\
\hline $\begin{array}{l}\text { Dom Peruzzo: "Retomar a reflexão é fundamental para manter } \\
\text { vivos os projetos urgentes" }\end{array}$ & $\begin{array}{l}\text { Vida cristã, catequese, assembleia, Igreja, } \\
\text { evangelização }\end{array}$ & $\mathrm{X}$ & \\
\hline $\begin{array}{l}\text { Dom Joel Portella: "o mundo está vivendo aceleração muito } \\
\text { rápida e a crise das mediações" }\end{array}$ & $\begin{array}{c}\text { Assembleia, Igreja, V conferência, conversão } \\
\text { pastoral }\end{array}$ & $\mathrm{X}$ & \\
\hline $\begin{array}{l}\text { Presidente da CNBB celebra missa de encerramento da } 55^{a} \\
\text { Assembleia Geral }\end{array}$ & Missa, vida cristã, assembleia, & $\mathrm{X}$ & \\
\hline $\begin{array}{l}\text { Encerrada a } 55^{a} \text { Assembleia dos bispos da CNBB realizada em } \\
\text { Aparecida (SP) }\end{array}$ & Assembleia, Igreja, mídia, vida cristã & $\mathrm{X}$ & \\
\hline $\begin{array}{l}\text { Quais os próximos passos do tema "Iniciação à vida cristã"? } \\
\text { Dom Rixen responde }\end{array}$ & $\begin{array}{c}\text { Assembleia, vida cristã, catequese, liturgia, } \\
\text { querigma }\end{array}$ & $\mathrm{X}$ & \\
\hline $\begin{array}{l}\text { Balanço final da } 36^{a} \text { Assembleia Ordinária do Celam realizada } \\
\text { em El Salvador }\end{array}$ & Episcopado, assembleia, pastorais, américa & $\mathrm{X}$ & \\
\hline $\begin{array}{l}\text { Il Encontro da Vida Consagrada Monástica e Contemplativa } \\
\text { começa na quarta }\end{array}$ & Vida consagrada, monaquismo & $\mathrm{X}$ & $\mathrm{X}$ \\
\hline $\begin{array}{l}\text { Carta do Conic sobre a Semana de Oração pela Unidade Cristã } \\
\text { propõe uma união mais plena }\end{array}$ & $\begin{array}{l}\text { Unidade, igrejas, reforma protestante, } \\
\text { reconcliação }\end{array}$ & $\mathrm{X}$ & \\
\hline $\begin{array}{l}\text { Coleção propõe preservação do patrimônio religioso da Igreja } \\
\text { no Brasil }\end{array}$ & $\begin{array}{l}\text { Cultura, patrimônio religioso, coleção, } \\
\text { educação }\end{array}$ & $\mathrm{X}$ & $\mathrm{X}$ \\
\hline $\begin{array}{l}\text { Futebol, fé e o bispo jogador: confira reflexões sobre o esporte } \\
\text { mais apreciado no Brasil }\end{array}$ & Futebol, time, fé, torcida, violência & $\mathrm{X}$ & $\mathrm{X}$ \\
\hline $\begin{array}{l}\text { Os cinco novos cardeais criados pelo papa Francisco segundo } \\
\text { profo Fernando Altemeyer }\end{array}$ & Cardeis, Igreja & $\mathrm{X}$ & \\
\hline Seminário Laudato Si' reúne lideranças do Xingu & $\begin{array}{l}\text { Lideranças, comunidades, carta, educação } \\
\text { ambiental }\end{array}$ & $\mathrm{X}$ & $\mathrm{X}$ \\
\hline $\begin{array}{l}\text { Conselho Episcopal Pastoral da CNBB delibera sobre a } \\
\text { Campanha da Fraternidade } 2018\end{array}$ & $\begin{array}{l}\text { Campanha da fraternidade, violência, vida } \\
\text { cristã, assembleia, comissões }\end{array}$ & $\mathrm{X}$ & \\
\hline $\begin{array}{l}\text { Responsáveis pela evangelização da juventude participam de } \\
\text { formação }\end{array}$ & Juventude, evangelização & $\mathrm{X}$ & $\mathrm{X}$ \\
\hline Ética na política & Ética, crise política, corrupção, sociedade & $x$ & \\
\hline A verdade vos libertará & Crise ética, verdade, corrupção, violência & $\mathrm{X}$ & \\
\hline A Conferência dos Bispos da América Latina e Caribe & $\begin{array}{l}\text { V conferência, documento, discipulos } \\
\text { missionarios, papa Bento XVI }\end{array}$ & $\mathrm{X}$ & \\
\hline $\begin{array}{l}\text { Imigração venezuelana para o Brasil aumenta vertiginosamente } \\
\text { nos últimos dois anos }\end{array}$ & Imigrantes, conflito político, venezuelanos & $\mathrm{X}$ & \\
\hline
\end{tabular}

Fonte: Autores, 2017

\section{PESQUISA EMPÍRICA: ANÁLISE DE DADOS}

A identificação das palavras-chave das notícias tem como critério diferenciar os temas para determinar as categorias das notícias do site da Conferência Nacional dos Bispos do Brasil. Dessa forma, as categorias dos acontecimentos noticiados pela entidade têm a seguinte nomeação: Notícias de fé e doutrina, Notícias institucionais, Notícias político-sociais, Notícias de educação e cultura, Notícias de meio-ambiente e Notícias de outros temas.

\section{Revista ALTERJOR}

Grupo de Estudos Alterjor: Jornalismo Popular e Alternativo (ECA-USP)

Ano 11 - Volume 02 - Edição 24 - Julho-Dezembro de 2021 


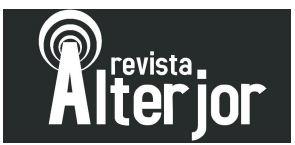

\section{NOTÍCIAS DE FÉ E DOUTRINA}

Identifica-se, com base nas datas definidas pelo método semana artificial, que a CNBB reporta conteúdo que apresenta as ações do episcopado da Igreja Católica no Brasil e suas áreas afins. Nas matérias que contêm as palavras-chave liturgia, educação, catequese, vida cristã, celebração, quaresma e Concílio do Vaticano II, é notória a construção de uma notícia voltada para a doutrina e fé da Igreja Católica, que discorre acerca dos princípios da vida cristã e seus ensinamentos, bem como os preceitos e orientações eclesiais e pastorais. Na matéria, publicada no dia 5 de maio de 2017, "Quais os próximos passos do tema 'Iniciação à vida cristã'? Dom Rixen responde", foi abordado um documento pela entidade, que pretende repensar a nova forma de fazer catequese, tendo em vista a iniciação à vida cristã, que se caracteriza por experiencial, celebrativa e centrada na doutrina da Igreja Católica. Em outra matéria, publicada dia 9 de março de 2017, "Setor Litúrgico apoia criação de especialização em 'Espaço Litúrgico: Arquitetura e Arte Sacra'", discorre sobre uma formação para os profissionais e agentes de pastoral litúrgica refletirem sobre o espaço celebrativo da Igreja, que possui significados que remetem ao Cristianismo. A categoria complicou seis matérias sobre fé e doutrina.

\section{NOTÍCIAS INSTITUCIONAIS}

Como instituição, a CNBB não poderia deixar de falar de si mesma. A partir da identificação das palavras-chaves: Conferência de Aparecida, conversão pastoral, assembleia, episcopado, nomeação e celebração, percebeu-se que algumas notícias destacam a presença dos bispos e versam sobre os encontros e assembleias da instituição. Além disso, trazem entrevistas dos bispos e outros assuntos, que evidenciam a ação do episcopado da Igreja no Brasil. A 55 assembleia Geral foi um fator determinante que apareceu em nove notícias das treze que tratavam do episcopado. Na categoria institucional, encontra-se matérias sobre nomeações, como "Nomeados bispos para Imperatriz (MA) e Joinville (SC)" e "Papa Francisco nomeia bispos para Itacoatiara (AM) e Campo Mourão (PR)”, publicadas no dia 19 de abril de 2017. Também há notas institucionais e encontros de organismos ligados à CNBB, como o texto publicado em 17 de abril de 2017, “Anuário Católico: nota de esclarecimento do Ceris”. Embora a CNBB

\section{Revista ALTERJOR}

Grupo de Estudos Alterjor: Jornalismo Popular e Alternativo (ECA-USP)

Ano 11 - Volume 02 - Edição 24 - Julho-Dezembro de 2021 Av. Professor Lúcio Martins Rodrigues, 443, Cidade Universitária, São Paulo, CEP: 05508-020 


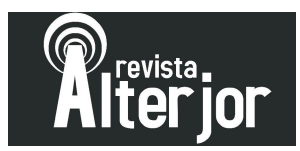

seja uma instituição de cunho religioso, percebeu-se que ela produz um número considerável de notícias referente à instituição. Durante os dias analisados, dezoito matérias foram registradas.

\section{NOTÍCIAS POLÍTICO-SOCIAIS}

As frequentes palavras: reforma da previdência, trabalhadores, manifestação, direitos, corrupção, reforma trabalhista, crise ética, violência e greve marcam uma instituição envolvida com os acontecimentos da crise política e social que ocorre nos últimos anos no Brasil. No total de treze textos publicados pela entidade, os bispos criticavam a situação política no governo de Michel Temer, apontado pelos artigos "Ética na política" e "A verdade vos libertará", ambos publicados dia 30 de maio. As matérias indicam uma entidade atenta às ações de seus líderes mundiais e à política no Brasil. $\mathrm{O}$ nome de Michel Temer é citado três vezes no conteúdo analisado.

Os termos como trabalhadores, pastorais sociais, comunidades, evangelização e imigrantes trataram das atribulações do trabalhador e também dos encontros das pastorais sociais que discutiam as dificuldades da realidade pastoral, social e política. Outro aspecto recorrente nos textos político-social é a dedicação aos mais pobres, que segundo a instituição são os que mais sofrem com as reformas. Desse modo, percebe-se que a instituição volta-se para os assuntos políticos com uma abordagem social.

\section{NOTÍCIAS DE EDUCAÇÃO E CULTURA}

Esta categoria aparece em três textos que transparecem as ações do episcopado no campo da educação e cultura. Por exemplo, a matéria publicada no dia 9 de março de 2017, “Comissão prepara Guia de Acolhida para Estudantes Estrangeiros”, apresenta uma iniciativa de uma das comissões da CNBB em preparar um guia de acolhimento para os estudantes estrangeiros que escolhem o Brasil para fazer intercâmbio. Em outra matéria, “Coleção propõe preservação do patrimônio religioso da Igreja no Brasil”, exprime a preocupação da instituição com cuidado e a preservação do patrimônio material e imaterial da Igreja. Educação foi a pauta do texto "Dom João Justino: 'Reformas pecam por não constituírem projeto consistente"”, publicado dia 27 de abril de 2017, que acentua

\section{Revista ALTERJOR}

Grupo de Estudos Alterjor: Jornalismo Popular e Alternativo (ECA-USP)

Ano 11 - Volume 02 - Edição 24 - Julho-Dezembro de 2021 Av. Professor Lúcio Martins Rodrigues, 443, Cidade Universitária, São Paulo, CEP: 05508-020 


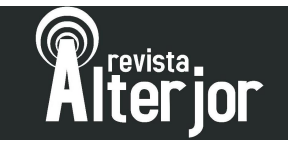

a crítica de um bispo sobre as políticas de educação e a desvalorização do professor que reflete no futuro do ensino de novos profissionais.

\section{NOTÍCIAS DE MEIO-AMBIENTE}

Nas matérias, o uso das palavras biomas, campanha da fraternidade, comunidades, educação ambiental indicam a ideia de uma instituição que vela pelo meio-ambiente. Entende-se que nas matérias escritas sobre a campanha da fraternidade e sobre o seminário do Xingu, com a intenção de chamar atenção para uma "conversão ecológica". A categoria meio-ambiente compilou duas notícias, sendo elas: "Admirar os biomas é contemplar a obra do criador", afirma cardeal Sergio da Rocha" e Seminário Laudato Si' reúne lideranças do Xingu, publicadas respectivamente em $1^{\circ}$ de março e 30 de maio de 2017.

\section{NOTÍCIAS DE OUTROS}

$\mathrm{Na}$ categoria outros, encontram-se duas notícias de temáticas individuais: juventude e esporte. Os termos time, fé, torcida e fé voltam-se para o esporte, caracterizando a paixão nacional pelo futebol. No único texto a palavra esporte é citada sete vezes, e fé aparece nove vezes. Já em "Responsáveis pela evangelização da juventude participam de formação", publicado dia 30 de maio de 2017, discorre sobre um encontro formativo voltado para juventude. Em apenas um parágrafo que foi veiculado, a palavra juventude foi citada cinco vezes.

No tipo de mídia, a foto tem forte impacto no conteúdo analisado. Percebe-se que imagem reflete o conteúdo presente nos textos e também traz significados diferentes dependendo da matéria, como "Oração dos Bispos do Regional Centro-Oeste da CNBB pelo atual momento do Brasil" e "Imigração venezuelana para o Brasil aumenta vertiginosamente nos últimos dois anos", publicadas respectivamente em 27 de abril e 30 de maio de 2017, em que denota uma certa preocupação com as situações expostas no texto. O fotojornalismo está presente em cerca de 95\% das imagens, registrando assembleias, encontros, formações e entrevistas coletivas. Entretanto, também se notou o aparecimento de imagens de folders de divulgação e perfil, como nas matérias sobre documentos eclesiais e artigos escritos pelos bispos.

\section{Revista ALTERJOR}

Grupo de Estudos Alterjor: Jornalismo Popular e Alternativo (ECA-USP)

Ano 11 - Volume 02 - Edição 24 - Julho-Dezembro de 2021 Av. Professor Lúcio Martins Rodrigues, 443, Cidade Universitária, São Paulo, CEP: 05508-020 


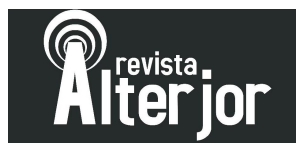

Notou-se ainda, onze links direcionados a outras páginas, sendo que dois eram para a leitura da notícia na íntegra nos portais dos regionais, pois no site da CNBB continha apenas o primeiro parágrafo e uma foto, ao passo que oito eram matérias de aprofundamento no tema abordado ou inscrições e programação de curso. Os links que disponibilizaram materiais para estudo revelam uma instituição que procura formar seu público com documentos eclesiais, cartas ou cursos. Apenas um link direcionava-se para a loja online ${ }^{4}$ da Conferência. Já os vídeos não são utilizados pela instituição.

Na produção de notícias do site da Conferência Nacional dos Bispos do Brasil (CNBB), é possível perceber os valores-notícia apresentados por Wolf(2003) e Hohlfeldt (2001). Nos critérios substantivos da notícia relacionados ao seu conteúdo e seus personagens, - que se define pelo grau e nível hierárquico dos indivíduos envolvidos no acontecimento, o impacto e interesse nacional, quantidade de pessoas envolvidas no acontecimento e relevância e significação do acontecimento quanto à evolução de uma determinada situação -, identifica o episcopado, pontificado e o presidente Michel Temer como as personalidade de maior noticiabilidade, quanto instituição de cunho religioso. Outro aspecto é doutrina, político-social, que a entidade tem perspectiva de seu público receptor e de seus interesses, além das notícias de interesse humano como o aumento da imigração.

Ainda segundo Wolf (2003) e Hohlfeldt (2001), as categorias relativas ao meio de informação, determinada pela quantidade de tempo usado para a veiculação da informação, caracteriza-se pela qualidade material visual e verbal, frequência da informação e a formatação do texto. Assim, é possível identificar o bom material visual, material verbal e o formato da CNBB. Com a mudança de site, as fotos apresentaram uma qualidade melhor, proporcionando um equilíbrio entre o material visual e o material verbal. Quanto ao formato, o texto da CNBB se reveste da linguagem jornalística, organizando-se em lide, desdobramentos e conclusão. Já nas categorias relativas ao público, estabelecida pela imagem que a instituição tem de seu público, nota-se que a estrutura narrativa permite a identificação dos personagens envolvidos e do fato narrado,

\footnotetext{
${ }^{4}$ Comunicação mercadológica é centrada no objetivo de gerar visibilidade de produtos e serviços da organização ou empresa, visando persuadir o público-alvo a adquiri-los.
}

\section{Revista ALTERJOR}

Grupo de Estudos Alterjor: Jornalismo Popular e Alternativo (ECA-USP)

Ano 11 - Volume 02 - Edição 24 - Julho-Dezembro de 2021 Av. Professor Lúcio Martins Rodrigues, 443, Cidade Universitária, São Paulo, CEP: 05508-020 


\section{Rieierer}

como a atuação do episcopado nas áreas cultura e educação, na qual todos podem atuar, como professores, alunos, artistas.

\section{CONSIDERAÇÕES FINAIS}

A proposta da pesquisa era compreender a notícia institucional, a partir da comunicação institucional. Atentou-se que a notícia institucional se caracteriza pela matéria que busca evidenciar a imagem da organização veiculada pela imprensa ou pela própria comunicação da organização. Cabe ressaltar que o objetivo visava investigar a produção de notícias do site da Conferência Nacional dos Bispos do Brasil (CNBB), indicando os valores notícia da instituição.

Compreendeu-se que os valores-notícia evidenciam somente uma parte dos critérios de noticiabilidade e correspondem aos aspectos interessantes, significativos e relevantes de um acontecimento para ser noticiado. No caso das notícias do site da CNBB, os valores-notícia que apareceram foram critérios substantivos da notícia relacionados ao seu conteúdo e seus personagens, critérios relativos ao meio de informação e relativas ao público. Percebeu-se que a instituição publica assuntos de impacto sobre a nação e de interesse nacional, como a política brasileira e direitos humanos.

Os critérios de noticiabilidade e os valores-notícia são um dos eixos da teoria de newsmaking, que dá ênfase à produção de informação, isto é, direciona para os estudos sobre o produtor da mensagem, especificamente as rotinas de trabalho que transformam o fato em notícia, como exposto na parte desta teoria. O newsmaking é constituído pela cultura profissional do jornalista, organização do trabalho e pelos processos produtivos da informação, ou seja, observa os critérios que definem a informação que será noticiável nos meios de comunicação e a rotina de produção da notícia. Esta pesquisa centrou-se apenas nos valores-notícia.

É importante ressaltar que esta análise é constituída de quarenta e quatro matérias no período de três meses de acordo com o método da semana construída, isto é, trata-se de um número relativamente alto para o período estabelecido. As notícias definidas podem caracterizar o perfil da CNBB e evidenciar alguns setores de atuação, pois a entidade atua em mais de dez frentes.

\section{Revista ALTERJOR}

Grupo de Estudos Alterjor: Jornalismo Popular e Alternativo (ECA-USP)

Ano 11 - Volume 02 - Edição 24 - Julho-Dezembro de 2021 Av. Professor Lúcio Martins Rodrigues, 443, Cidade Universitária, São Paulo, CEP: 05508-020 


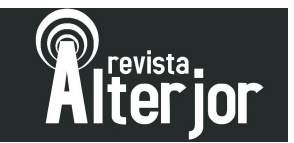

Nessas considerações finais, salienta-se o relacionamento da Igreja e comunicação. Os documentos da Igreja Católica abordam visivelmente a comunicação desde 1963, com o decreto Inter Mirifica do Concílio do Vaticano II. No acervo do Vaticano, ainda estão presente os documentos sobre comunicação: Communio et Progressio, Aetatis Novae, Igreja e Internet, Ética na Internet e Ética nas Comunicações Sociais. No Brasil, a CNBB tratou na Campanha da Fraternidade de 1989 o tema "Fraternidade e Comunicação". Em 1997, foi publicado o subsídio "A Igreja e a Comunicação rumo ao novo milênio" e o Diretório de Comunicação da Igreja no Brasil em 2014. Salienta-se ainda, a pesquisa bibliográfica, teórica e a análise das notícias fizeram esta pesquisa ser válida para refletir sobre a importância de ter um olhar crítico sobre a produção de conteúdo noticioso pelas instituições.

\section{REFERÊNCIAS}

BARDIN, Laurence. Análise de conteúdo. Lisboa: Edições 70, 2009.

BARROS, Raimundo Caramuru. Gênese e Consolidação da CNBB no contexto de uma Igreja em plena renovação. In: PASTORAL, Instituto Nacional. Presença Pública da Igreja no Brasil (1925-2002): Jubileu de Ouro da CNBB. São Paulo: Paulinas, 2003. p. 13-69

BEOZZO, Pe. José Oscar. A recepção do Vaticano II na Igreja do Brasil. In: PASTORAL, Instituto Nacional. Presença Pública da Igreja no Brasil (1925-2002): Jubileu de Ouro da CNBB. São Paulo: Paulinas, 2003. p. 13-69

BRANDÃO, Elizabeth; CARVALHO, Bruno. Imagem Corporativa: Marketing da Ilusão. In: DUARTE, Jorge (Org.). Assessoria de imprensa e relacionamento com a mídia: teoria e técnica. São Paulo: Atlas, 2003.

CONFERÊNCIA NACIONAL DOS BISPOS DO BRASIL. Quem somos. Disponível em: <cnbb.org.br>. Acesso em: 21 abr. 2017

CONFERÊNCIA NACIONAL DOS BISPOS DO BRASIL. Comunicação para a verdade e a paz: Campanha da fraternidade 1989 manual. Brasília, DF: Salesianas, 1989.

CONFERÊNCIA NACIONAL DOS BISPOS DO BRASIL. Igreja e comunicação rumo ao novo milênio. Estudos da CNBB 75. 2. ed. São Paulo: Paulus, 1997.

CONFERÊNCIA NACIONAL DOS BISPOS DO BRASIL. DIRETÓRIO DE COMUNICAÇÃO. In: Documentos da CNBB. São Paulo: Edições CNBB, 2014.

\section{Revista ALTERJOR}

Grupo de Estudos Alterjor: Jornalismo Popular e Alternativo (ECA-USP)

Ano 11 - Volume 02 - Edição 24 - Julho-Dezembro de 2021 Av. Professor Lúcio Martins Rodrigues, 443, Cidade Universitária, São Paulo, CEP: 05508-020 


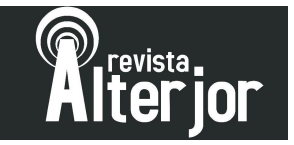

GODOY, Pe. Manuel José de. A CNBB e o processo de evangelização do Brasil. In: PASTORAL, Instituto Nacional. Presença Pública da Igreja no Brasil (1925-2002): Jubileu de Ouro da CNBB. São Paulo: Paulinas, 2003. p. 387-396

HOHLFELDT, Antonio; MARTINO, Luiz C; FRANÇA, Vera Veiga. Teorias da Comunicação: conceitos, escolas e tendências. Rio de Janeiro: Vozes, 2003

KUNSCH, Margarida Maria Krohling. Planejamento de relações públicas na comunicação integrada. São Paulo: Summus, 2003.

LAGO, Claúdia; BENETTI, Marcia (Coord.). Metodologia de pesquisa em jornalismo. 2. ed. Petrópolis, RJ: Vozes, 2008

PENA, Felipe. Teoria do jornalismo. 3. ed. São Paulo: Contexto, 2012.

PUNTEL, Joana T. A IGREJA A CAMINHO NA COMUNICAÇÃO. Teocomunicação, Rio Grande do Sul, v. 41, n. 2, p.221-242, jul/dez. 2011. Quadrimestral. Disponível em: $<$ http://revistaseletronicas.pucrs.br>. Acesso em: 22 maio 2017.

SANTAELLA, Lucia. Comunicação e Pesquisa. São Paulo: Hacker, 2006

São Paulo: Ed. Salesiana Dom Bosco,1989.

SOARES, Ismar O. Do santo ofício à libertação. São Paulo: Edições Paulinas, 1988

TORQUATO, Gaudêncio. Comunicação empresarial, comunicação institucional: conceito, estratégias, sistemas, estrutura, planejamento e técnicas. São Paulo: Summus Editorial, 1986.

TRAQUINA, Nelson. Teorias do jornalismo. 3. ed. Florianópolis: Insular, 2013.

VATICANO. Decreto Inter Mirifica sobre os meios de comunicação social. 4 dez. 1966. Disponível em:

$<$ http://www.vatican.va/archive/hist_councils/ii_vatican_council/documents/vatii_decree_19631204_inter-mirifica_po.html>. Acesso em: 7 out. 2016.

VATICANO. Instrução Pastoral Communio et ProgressIo sobre os meios de comunicação social. 3 mai. 1971. Disponível em:

$<$ http://www.vatican.va/roman_curia/pontifical_councils/pccs/documents/rc_pc_pccs_d oc_23051971_communio_po.html>. Acesso em: 20 mai. 2017.

VATICANO. Pontifício Conselho para as Comunicações Sociais: Ética na Internet. 22 fev. 2002. Disponível em:

$<$ http://www.vatican.va/roman_curia/pontifical_councils/pccs/documents/rc_pc_pccs_d oc_20020228_ethics-internet_po.html>. Acesso em: 18 maio 2017.

VATICANO. Pontifício Conselho para as Comunicações Sociais: Ética nas Comunicações. 4 jun. 2000. Disponível em:

$<$ http://www.vatican.va/roman_curia/pontifical_councils/pccs/documents/rc_pc_pccs_d oc_20000530_ethics-communications_po.html>. Acesso em: 18 maio 2017.

VATICANO. Pontifício Conselho para as Comunicações Sociais: Igreja e Internet. 22 fev. 2002. Disponível em:

\section{Revista ALTERJOR}

Grupo de Estudos Alterjor: Jornalismo Popular e Alternativo (ECA-USP)

Ano 11 - Volume 02 - Edição 24 - Julho-Dezembro de 2021 Av. Professor Lúcio Martins Rodrigues, 443, Cidade Universitária, São Paulo, CEP: 05508-020 


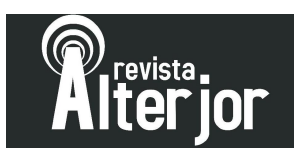

$<$ http://www.vatican.va/roman_curia/pontifical_councils/pccs/documents/rc_pc_pccs_d oc_20020228_church-internet_po.html > Acesso em: 27 de set. 2016

VATICANO. Pontifício Conselho para as Comunicações Sociais: Instrução pastoral Aetatis novae no vigésimo aniversário da Communio et progressio: uma revolução nas comunicações. 2. ed. São Paulo: Paulinas, 1999.

WOLF, Mauro. Teorias da Comunicação: mass media: contexto e paradigmas, novas tendências, efeitos a longo prazo, o newsmaking. Lisboa: Presença, 2003.

WOLF, Mauro. Teorias das comunicações de massa. São Paulo: Martins Fontes, 2003

\section{CORPUS DE ANÁLISE}

CONFERENNCIA NACIONAL DOS BISPOS DO BRASIL. "Admirar os biomas é contemplar a obra do criador”, afirma cardeal Sergio da Rocha. 01 mar. 2017

Disponível em:

$<$ http://www.cnbb.org.br/arquivo/index.php?option=com_content\&amp; view=article\&a mp;id=20365:admirar-os-biomas-e-contemplar-a-obra-do-criador-afirma-cardealsergio-da-rocha-3\&amp;catid=114\&amp;Itemid=106> Acesso em: 17 out. 2017

CONFERÊNCIA NACIONAL DOS BISPOS DO BRASIL. Setor Litúrgico apoia criação de especialização em "Espaço Litúrgico: Arquitetura e Arte Sacra”. 03 mar. 2017. Disponível em:

$<$ http://www.cnbb.org.br/arquivo/index.php?option=com_content\&amp; view=article\&a mp;id=20421:setor-liturgico-apoia-criacao-de-especializacao-em-espaco-liturgicoarquitetura-e-arte-sacra\&amp;catid=114\&amp;Itemid=106> Acesso em: 17 out. 2017

CONFERENNCIA NACIONAL DOS BISPOS DO BRASIL. Comissão prepara Guia de Acolhida para Estudantes Estrangeiros. 09 mar. 2017. Disponível em:

$<$ http://www.cnbb.org.br/arquivo/index.php?option=com_content\&amp; view=article\&a $\mathrm{mp} ;$ id=20416: comissao-prepara-guia-de-acolhida-para-estudantesestrangeiros\&amp;catid=114\&amp;Itemid=106 > Acesso em: 18 out. 2017

CONFERÊNCIA NACIONAL DOS BISPOS DO BRASIL. Comunidade na sede da CNBB realiza momento penitencial "24 horas para o Senhor". 17 mar. 2017. Disponível em:

$<\mathrm{http}$ ://www.cnbb.org.br/arquivo/index.php?option=com_content\&amp;view=article\&a mp;id=20463: comunidade-na-sede-da-cnbb-realiza-momento-penitencial-24-horaspara-o-senhor\&amp;catid=114\&amp;Itemid=106> Acesso em: 18 out. 2017

CONFERÊNCIA NACIONAL DOS BISPOS DO BRASIL. Anuário Católico: nota de esclarecimento do Ceris. 17 mar. 2017. Disponível em:

$<$ http://www.cnbb.org.br/arquivo/index.php?option=com_content\&amp; view=article\&a $\mathrm{mp} ; \mathrm{id}=20467$ :anuario-catolico-nota-de-esclarecimento-doceris\&amp;catid=114\&amp;Itemid=106> Acesso em: 18 out. 2017

CONFERÊNCIA NACIONAL DOS BISPOS DO BRASIL. Ex-vice-presidente da CNBB faleceu aos 88 anos de idade em Recife (PE). 26 mar. 2017. Disponível em: $<$ http://www.cnbb.org.br/arquivo/index.php?option=com_content\&amp; view=article\&a

\section{Revista ALTERJOR}

Grupo de Estudos Alterjor: Jornalismo Popular e Alternativo (ECA-USP)

Ano 11 - Volume 02 - Edição 24 - Julho-Dezembro de 2021 Av. Professor Lúcio Martins Rodrigues, 443, Cidade Universitária, São Paulo, CEP: 05508-020 


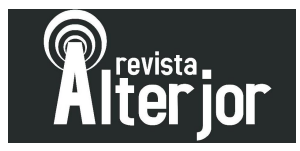

mp;id=20516:ex-vice-presidente-da-cnbb-faleceu-aos-88-anos-de-idade-em-recifepe\&amp;catid=114\&amp;Itemid=106> Acesso em: 18 out. 2017

CONFERÊNCIA NACIONAL DOS BISPOS DO BRASIL. CNBB envia mensagem de condolências pelo falecimento de dom Marcelo Carvalheira. 26 mar. 2017. Disponível em:

$<$ http://www.cnbb.org.br/arquivo/index.php?option=com_content\&amp; view=article\&a mp;id=20517:cnbb-envia-mensagem-de-condolencias-pelo-falecimento-de-dommarcelo-carvalheira\&amp;catid=114\&amp;Itemid=106> Acesso em: 18 out. 2017

CONFERÊNCIA NACIONAL DOS BISPOS DO BRASIL. Material apresenta pronunciamentos sobre Reforma da Previdência. 03 bar. 2017. Disponível em:

$<\mathrm{http}$ ://www.cnbb.org.br/arquivo/index.php?option=com_content\&amp; view=article\&a $\mathrm{mp} ; \mathrm{id}=20563$ :material-apresenta-pronunciamentos-sobre-reforma-daprevidencia\&amp;catid=114\&amp;Itemid=106> Acesso: 19 out. 2017

CONFERÊNCIA NACIONAL DOS BISPOS DO BRASIL. Nomeados bispos para Imperatriz (MA) e Joinville (SC). 19 abr. 2017. Disponível em:

$<$ http://www.cnbb.org.br/arquivo/index.php?option=com_content\&amp; view=article\&a mp;id=20621:nomeados-bispos-para-imperatriz-ma-e-joinvillesc\&amp;catid=114\&amp;Itemid=106> Acesso em: 19 out. 2017

CONFERÊNCIA NACIONAL DOS BISPOS DO BRASIL. Papa Francisco nomeia bispos para Itacoatiara (AM) e Campo Mourão (PR). 19 abr. 2017. Disponível em: $<$ http://www.cnbb.org.br/arquivo/index.php?option=com_content\&amp; view=article\&a mp;id=20620:papa-francisco-nomeia-bispos-para-itacoatiara-am-e-campo-mouraopr\&amp;catid=114\&amp;Itemid=106> Acesso em: 19 out. 2017

CONFERÊNCIA NACIONAL DOS BISPOS DO BRASIL. Vaticano emite nota de esclarecimento sobre carta do Papa a Michel Temer. 19 abr. 2017. Disponível em: $<\mathrm{http}$ ://www.cnbb.org.br/arquivo/index.php?option=com_content\&amp; view=article\&a mp;id=20622: \&\&amp;catid=114\&amp;Itemid=106> Acesso em: 20 out. 2017

CONFERENCIA NACIONAL DOS BISPOS DO BRASIL. Reforma da Previdência: CNBB, OAB e Conselho Federal de Economia reiteram posição em nota conjunta. 19 abr. 2017. Disponível em:

$<\mathrm{http}$ ://www.cnbb.org.br/arquivo/index.php?option=com_content\&amp; view=article\&a $\mathrm{mp} ; \mathrm{id}=20623$ :em-nota-conjunta-cnbb-reitera-sua-posicao-sobre-a-reforma-daprevidencia\&amp;catid=114\&amp;Itemid=106> Acesso em: 20 out. 2017

CONFERENCIA NACIONAL DOS BISPOS DO BRASIL. Mensagem da CNBB aos trabalhadores (as) do Brasil: "O dia do trabalhador é celebrado em meio a um ataque aos direitos conquistados". 27 abr. 2017. Disponível em: <http://cnbb.net.br/mensagemda-cnbb-aos-trabalhadores-e-trabalhadoras-do-brasil-encorajamos-a-organizacaodemocratica-e-mobilizacoes-pacificas/> Acesso em: 23 out. 2017

CONFERÊNCIA NACIONAL DOS BISPOS DO BRASIL. Dom Geraldo Lyrio: “A posição da Igreja não é de tomar como bandeira sua, alguma bandeira defendida por este ou por aquele grupo". 27 abr. 2017. Disponível em: <http://cnbb.net.br/domgeraldo-lyrio-a-posicao-da-igreja-nao-e-de-tomar-como-bandeira-sua-alguma-bandeira-

\section{Revista ALTERJOR}

Grupo de Estudos Alterjor: Jornalismo Popular e Alternativo (ECA-USP)

Ano 11 - Volume 02 - Edição 24 - Julho-Dezembro de 2021 Av. Professor Lúcio Martins Rodrigues, 443, Cidade Universitária, São Paulo, CEP: 05508-020 


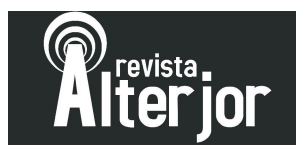

defendida-por-este-ou-por-aquele-grupo-a-posicao-da-igreja-se-situa-no-nivel-dodiscurso-etico-e-da-defesa-d/> Acesso em: 23 out. 2017

CONFERÊNCIA NACIONAL DOS BISPOS DO BRASIL. Cardeal Odilo Pedro

Scherer: "O povo tem direito de se manifestar, de pedir esclarecimentos". 27 abr. 2017.

Disponível em: $<$ http://cnbb.net.br/cardeal-scherer-o-povo-tem-direito-de-semanifestar/> Acesso em: 24 out. 2017

CONFERÊNCIA NACIONAL DOS BISPOS DO BRASIL. Dom Esmeraldo Barreto: "estávamos vivendo e continuamos vivendo uma mudança de época". 27 abr. 2017. Disponível em: $<\mathrm{http}: / / \mathrm{cnbb}$.net.br/dom-esmeraldo-barreto-continuamos-vivendo-umamudanca-de-epoca/> Acesso em: 24 out. 2017

CONFERÊNCIA NACIONAL DOS BISPOS DO BRASIL. Núncio Apostólico no Brasil celebra missa na Assembleia dos bispos e fala sobre testemunho. 27 abr. 2017. Disponível em: <http://cnbb.net.br/nuncio-apostolico-no-brasil-celebra-missa-daassembleia-dos-bispos-e-fala-sobre-testemunho/> Acesso em: 24 out. 2017

CONFERÊNCIA NACIONAL DOS BISPOS DO BRASIL. Pastoral do Menor: "Dê Oportunidade. Faça diferente, ninguém nasce infrator”. 27 abr. 2017. Disponível em: $<$ http://cnbb.net.br/pastoral-do-menor-lanca-campanha-de-oportunidade-faca-diferenteninguem-nasce-infrator/> Acesso em: 25 out. 2017.

CONFERÊNCIA NACIONAL DOS BISPOS DO BRASIL. Pastorais Sociais realizaram encontro regional em Guarapuava (PR). 27 abr. 2017. Disponível em: $<\mathrm{http}$ //cnbb.net.br/pastorais-sociais-realizam-encontro-regional/> Acesso em: 25 out. 2017

CONFERÊNCIA NACIONAL DOS BISPOS DO BRASIL. Bispos novos são apresentados na 55ª Assembleia Geral da CNBB. 27 abr. 2017. Disponível em: $<$ http://cnbb.net.br/bispos-novos-sao-apresentados-na-55a-assembleia-geral-da-cnbb/> Acesso em: 26 out.

CONFERÊNCIA NACIONAL DOS BISPOS DO BRASIL. Oração dos Bispos do Regional Centro-Oeste da CNBB pelo atual momento do Brasil. 27 abr. 2017. Disponível em: $<$ http://cnbb.net.br/oracao-dos-bispos-do-regional-centro-oeste-dacnbb-pelo-atual-momento-do-brasil/> Acesso em: 26 out. 2017

CONFERÊNCIA NACIONAL DOS BISPOS DO BRASIL. Dia do Trabalhador: Pastoral Operária divulga nota. 27 abr. 2017. Disponível em: $<$ http://cnbb.net.br/dia-dotrabalhador-pastoral-operaria-divulga-nota/> Acesso: 26 out. 2017

CONFERÊNCIA NACIONAL DOS BISPOS DO BRASIL. Estadão conteúdo: “D. Leonardo espera que a greve geral seja pacífica e sem violência”. 27 abr. 2017. Disponível em: $<$ http://cnbb.net.br/estadao-conteudo-d-leonardo-espera-que-a-grevegeral-seja-pacifica-e-sem-violencia/> Acesso em: 26 out. 2017

CONFERÊNCIA NACIONAL DOS BISPOS DO BRASIL. Centro Pe. Vitor Coelho de Almeida, espaço multiuso, recebe bispos de todo o Brasil. 27 abr. 2017. Disponível em: $<$ http://cnbb.net.br/centro-pe-vitor-coelho-de-almeida-espaco-multiuso-recebe-bisposde-todo-o-brasil/> Acesso em: 27 out. 2017

\section{Revista ALTERJOR}

Grupo de Estudos Alterjor: Jornalismo Popular e Alternativo (ECA-USP)

Ano 11 - Volume 02 - Edição 24 - Julho-Dezembro de 2021 Av. Professor Lúcio Martins Rodrigues, 443, Cidade Universitária, São Paulo, CEP: 05508-020 


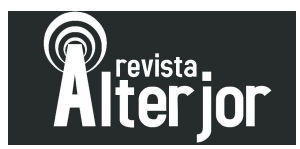

CONFERÊNCIA NACIONAL DOS BISPOS DO BRASIL. Dom Leomar: "a grande preocupação é formar discípulos e não adeptos do cristianismo". 27 abr. 2017. Disponível em: $<$ http://cnbb.net.br/dom-leomar-a-grande-preocupacao-e-formardiscipulos-e-nao-adeptos-do-cristianismo/> Acesso em: 27 out. 2017

CONFERÊNCIA NACIONAL DOS BISPOS DO BRASIL. Dom João Justino: "Reformas pecam por não constituírem projeto consistente". 27 abr. 2017. Disponível em: $<$ http://cnbb.net.br/dom-joao-justino-e-muito-comum-a-atitude-de-confiar-a-escolaa-educacao-mas-nao-haver-uma-participacao-da-familia-na-educacao/> Acesso em: 27 out. 2017

CONFERÊNCIA NACIONAL DOS BISPOS DO BRASIL. Dom Peruzzo: "Retomar a reflexão é fundamental para manter vivos os projetos urgentes". 27 abr. 2017. Disponível em: $<$ http://cnbb.net.br/dom-peruzzo-retomar-a-reflexao-e-fundamentalpara-manter-vivos-os-projetos-que-como-igreja-consideramos-urgentes/> Acesso: 30 out. 2017

CONFERÊNCIA NACIONAL DOS BISPOS DO BRASIL. Dom Joel Portella: “o mundo está vivendo aceleração muito rápida e a crise das mediações". 27 abr. 2017. Disponível em: $<$ http://cnbb.net.br/dom-joel-portella-o-mundo-esta-vivendo-aceleracaomuito-rapida-e-a-crise-das-mediacoes/> Acesso em: 30 out. 2017

CONFERÊNCIA NACIONAL DOS BISPOS DO BRASIL. Presidente da CNBB celebra missa de encerramento da 55 a Assembleia Geral. 05 mai. 2017. Disponível em: $<$ http://cnbb.net.br/presidente-da-cnbb-celebra-missa-de-encerramento-da-55aassembleia-geral/> Acesso em: 30 out. 2017

CONFERÊNCIA NACIONAL DOS BISPOS DO BRASIL. Encerrada a $55^{\mathrm{a}}$

Assembleia dos bispos da CNBB realizada em Aparecida (SP). 05 mai. 2017.

Disponível em: $<$ http://cnbb.net.br/encerrada-a-55a-assembleia-dos-bispos-da-cnbbrealizada-em-aparecida-sp/> Acesso em: 30 out. 2017

CONFERÊNCIA NACIONAL DOS BISPOS DO BRASIL. Quais os próximos passos do tema "Iniciação à vida cristã"? Dom Rixen responde. 05 mai. 2017. Disponível em: $<$ http://cnbb.net.br/a-55a-assembleia-geral-chega-ao-fim-quais-os-proximos-passospara-desdobrar-o-tema-iniciacao-a-vida-crista/> Acesso em: 31 out. 2017

CONFERÊNCIA NACIONAL DOS BISPOS DO BRASIL. Balanço final da $36^{\mathrm{a}}$ Assembleia Ordinária do Celam realizada em El Salvador. 13 mai. 2017. Disponível em: $<$ http://cnbb.net.br/balanco-final-da-36a-assembleia-ordinaria-do-celam-realizadaem-el-salvador/> Acesso em: 31 out. 2017

CONFERENCIA NACIONAL DOS BISPOS DO BRASIL. II Encontro da Vida Consagrada Monástica e Contemplativa começa na quarta. 22 mai. 2017. Disponível em: $<$ http://cnbb.net.br/a-vida-contemplativa-e-uma-dimensao-importantissima-daigreja-afirma-dom-jaime-spengler/> Acesso em: 01 nov. 2017

CONFERENCIA NACIONAL DOS BISPOS DO BRASIL. Carta do Conic sobre a Semana de Oração pela Unidade Cristã propõe uma união mais plena. 22 mai. 2017.

\section{Revista ALTERJOR}

Grupo de Estudos Alterjor: Jornalismo Popular e Alternativo (ECA-USP)

Ano 11 - Volume 02 - Edição 24 - Julho-Dezembro de 2021 Av. Professor Lúcio Martins Rodrigues, 443, Cidade Universitária, São Paulo, CEP: 05508-020 


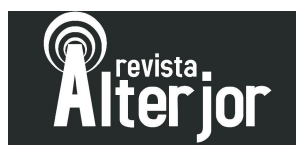

Disponível em: $<$ http://cnbb.net.br/carta-das-igrejas-membro-do-conic-sobre-a-semanade-oracao-pela-unidade-crista-propoe-a-reconciliacao/> Acesso em: 03 nov. 2017

CONFERÊNCIA NACIONAL DOS BISPOS DO BRASIL. Coleção propõe preservação do patrimônio religioso da Igreja no Brasil. 22 mai. 2017. Disponível em: $<$ http://cnbb.net.br/colecao-pastoral-da-cultura-propoe-levantamento-e-preservacao-dariqueza-e-diversidade-do-patrimonio-religioso-da-igreja-do-brasil/> Acesso em: 06 nov. 2017

CONFERÊNCIA NACIONAL DOS BISPOS DO BRASIL. Futebol, fé e o bispo jogador: confira reflexões sobre o esporte mais apreciado no Brasil. 22 mai. 2017. Disponível em: <http://cnbb.net.br/futebol-fe-e-o-bispo-jogador/> Acesso em: 07 nov. 2017

CONFERÊNCIA NACIONAL DOS BISPOS DO BRASIL. Os cinco novos cardeais criados pelo papa Francisco segundo prof ${ }^{\circ}$ Fernando Altemeyer. 22 mai. 2017. Disponível em: $<$ http://cnbb.net.br/os-cinco-novos-cardeais-criados-pelos-papafrancisco-segundo-prof-fernando-altemeyer/> Acesso em: 07 nov. 2017

CONFERÊNCIA NACIONAL DOS BISPOS DO BRASIL. Seminário Laudato Si' reúne lideranças do Xingu. 30 mai. 2017. Disponível em: $<$ http://cnbb.net.br/seminariolaudato-si-reune-liderancas-do-xingu/> Acesso em: 08 nov. 2017

CONFERÊNCIA NACIONAL DOS BISPOS DO BRASIL. Conselho Episcopal Pastoral da CNBB delibera sobre a Campanha da Fraternidade 2018. 30 mai. 2017. Disponível em: $<$ http://cnbb.net.br/conselho-episcopal-pastoral-da-cnbb-delibera-sobrea-campanha-da-fraternidade-2018-2/> Acesso em: 08 nov. 2017

CONFERÊNCIA NACIONAL DOS BISPOS DO BRASIL. Responsáveis pela evangelização da juventude participam de formação. 30 mai. 2017. Disponível em: $<\mathrm{http}$ //cnbb.net.br/responsaveis-pela-evangelizacao-da-juventude-participam-deformacao/> Acesso em: 09 nov. 2017

CONFERÊNCIA NACIONAL DOS BISPOS DO BRASIL. Ética na política. 30 mai. 2017. Disponível em: <http://cnbb.net.br/etica-na-politica/> Acesso em: 10 nov. 2017

CONFERÊNCIA NACIONAL DOS BISPOS DO BRASIL. A verdade vos libertará. 30 mai. 2017. Disponível em: <http://cnbb.net.br/a-verdade-vos-libertara/> Acesso em: 13 nov. 2017

CONFERÊNCIA NACIONAL DOS BISPOS DO BRASIL. A Conferência dos Bispos da América Latina e Caribe. Disponível em: $<$ http://cnbb.net.br/a-conferencia-geral-doepiscopado-latino-americano-e-caribenho/> Acesso em: 13 nov. 2017

CONFERÊNCIA NACIONAL DOS BISPOS DO BRASIL. Imigração venezuelana para o Brasil aumenta vertiginosamente nos últimos dois anos. 30 mai. 2017. Disponível em: $<$ http://cnbb.net.br/imigracao-venezuelana-para-o-brasil-aumentavertiginosamente-no-ultimos-dois-anos/> Acesso em: 13 out. 2017

\section{Revista ALTERJOR}

Grupo de Estudos Alterjor: Jornalismo Popular e Alternativo (ECA-USP)

Ano 11 - Volume 02 - Edição 24 - Julho-Dezembro de 2021 Av. Professor Lúcio Martins Rodrigues, 443, Cidade Universitária, São Paulo, CEP: 05508-020 